IZA DP No. 8787

Effects of Changes in Pensions on the Age of First Benefit Receipt: Regression Discontinuity Evidence from Repatriated Ethnic Germans

Patrick A. Puhani

Falko Tabbert

January 2015 


\title{
Effects of Changes in Pensions on the Age of First Benefit Receipt: Regression Discontinuity Evidence from Repatriated Ethnic Germans
}

\author{
Patrick A. Puhani \\ Leibniz Universität Hannover \\ and IZA \\ Falko Tabbert \\ Leibniz Universität Hannover
}

Discussion Paper No. 8787

January 2015

IZA

P.O. Box 7240

53072 Bonn

Germany

Phone: +49-228-3894-0

Fax: +49-228-3894-180

E-mail: iza@iza.org

Any opinions expressed here are those of the author(s) and not those of IZA. Research published in this series may include views on policy, but the institute itself takes no institutional policy positions. The IZA research network is committed to the IZA Guiding Principles of Research Integrity.

The Institute for the Study of Labor (IZA) in Bonn is a local and virtual international research center and a place of communication between science, politics and business. IZA is an independent nonprofit organization supported by Deutsche Post Foundation. The center is associated with the University of Bonn and offers a stimulating research environment through its international network, workshops and conferences, data service, project support, research visits and doctoral program. IZA engages in (i) original and internationally competitive research in all fields of labor economics, (ii) development of policy concepts, and (iii) dissemination of research results and concepts to the interested public.

IZA Discussion Papers often represent preliminary work and are circulated to encourage discussion. Citation of such a paper should account for its provisional character. A revised version may be available directly from the author. 


\section{ABSTRACT \\ Effects of Changes in Pensions on the Age of First Benefit Receipt: Regression Discontinuity Evidence from Repatriated Ethnic Germans*}

To estimate the effects of large cuts in pensions on the age of first benefit receipt, we exploit two natural experiments in which such cuts affect a group of repatriated ethnic German workers. The pensions were cut by about $12 \%$, yet, according to our regression discontinuity estimates based on administrative pension data, there was no significant delay in the age of first pension receipt. Based on additional data sources, we find (i) that almost all pension recipients of our study population had left the labor force and (ii) that repatriated ethnic Germans hold similar jobs and exhibit similar retirement behavior as low-skilled Germans. The results are consistent with low-skilled workers in Germany being frozen in a cornersolution equilibrium in which the optimal choice is to retire as early as possible.

JEL Classification: J26, H55

Keywords: policy, evaluation, pension reform, labor supply, retirement

Corresponding author:

Patrick A. Puhani

Leibniz Universität Hannover

Institut für Arbeitsökonomik

Königsworther Platz 1

D-30167 Hannover

Germany

E-mail: puhani@aoek.uni-hannover.de

\footnotetext{
* Part of this research was supported by the German Research Foundation (DFG) within the project 'Labour Market Effects of Social Policy', which is part of the research initiative 'Flexibility in Heterogeneous Labour Markets'. This research would not have been possible without the support of employees of the German Pension Insurance's Research Data Center. We are grateful to the editor Steven Haider and two anonymous referees, as well as Steffen Altmann, Antonio Brettschneider, David Card, Florent Fremigacci, Corrado Giulietti, Torsten Hammer, Ingmar Hansen, Jürgen Hofmann, Andrew Oswald, Anna Katharina Pikos, Craig Riddell, Emmanuel Saez, Hilmar Schneider, Michael Stegmann, Alexander Straub, Konstantinos Tatsiramos, Friederike von Haaren, Andrea Weber, seminar participants at CLE, UC Berkeley, at IZA, Bonn, the German Economic Association, the European Association of Labour Economists, at the Universities of Frankfurt and Nuremberg, and at the research initiative's IAB meeting in Nuremberg for helpful comments. All remaining errors are our own.
} 


\section{Introduction}

Governments have been making pension systems less generous in many industrialized countries. Increasing life expectancies, low retirement ages in many continental European countries like France, Germany, Italy or Spain (OECD, 2011 p. 43), and the fiscal implications of the current financial crisis will keep pension systems in the focus of policy reforms. We might expect these reforms to have positive effects on the labor supply, notably for older workers. This should especially be true in the presence of myopic savings behavior, liquidity constraints, or unexpected pension cuts (cf. Card, Chetty, and Weber, 2007). These potential labor supply effects may in turn induce important fiscal effects by increasing tax and social security revenues and decreasing pension fund payouts, at least if those who retire later pay comparatively more into the pension systems than they receive in terms of increased pension benefits, which seems to be the case in most OECD countries (Queisser and Whitehouse, 2006, p. 29). The size of these pension reform effects, however, depends on the labor supply elasticity of mostly older workers, a factor that is hard to determine empirically because of the rarity of exogenous shocks to budget constraints (wages, pension rights).

Our paper is one of the very few studies to investigate large exogenous cuts in pensions by way of natural experiments. Studies that analyze exogenous pension cuts are Krueger and Pischke (1992), Jensen and Richter (2003), and Snyder and Evans (2006). Danzer (2013) investigates a large pension increase in Ukraine, Mastrobuoni (2009) analyses small increases in the normal retirement age for successive cohorts in the United States, whereas Liebman, Luttmer, and Seif (2009) exploit discontinuities in the link between social security taxes and benefits to estimate labor supply elasticities in the United States. We use administrative data from the German pension register to estimate pension receipt reactions to two large pension cuts during the 1990s affecting only repatriated ethnic Germans. The repatriated ethnic Germans studied here mainly came from source countries such as the former Soviet Union or Romania, their original countries of residence. 
The two natural experiments investigated here both reduce pension rates and hence increase the price of leisure (see Figure A1 in the Appendix). This is different from the natural experiment analyzed by Danzer (2013) for the Ukraine, where pension receipt did not require workers to reduce their labor supply as in the German early retirement schemes that most of our study population made use of. Therefore, we would expect pension cuts to induce workers to start drawing pensions later. Because the pension cuts were based on the repatriation date and enacted retrospectively, they can be analyzed using regression discontinuity designs. However, we find no significant effects of these reforms on the age of first benefit receipt. Because most repatriated ethnic Germans started to draw pensions under one of several early retirement schemes, that were not actuarially decreasing the pension level to adjust for a longer duration of pension receipt, we conclude that the population studied is bogged down in a "corner solution" made up of incentives to draw benefits as early as possible. For example, early pension receipt at age 60 (the modal age for first pension receipt in this study) requires retirement in that the pension would be completely withdrawn if a person were to earn more than "marginal earnings" (currently around $€ 450$ per month).

The German case investigated in this study can be seen as an example of how some European welfare systems provide few labor supply incentives/opportunities for older low-skilled workers: Queisser and Whitehouse (2006, p. 29) show that pension reductions in case of early pension receipt are below actuarially neutral reductions in the vast majority of OECD countries.

Although the natural experiments analyzed here refer to the specific group of older repatriated ethnic Germans, we demonstrate that this group of older repatriated ethnic Germans resembles low-skilled (i.e. without vocational training/apprenticeship) workers in Germany (i) in terms of their job distribution, (ii) in terms of their age of first pension receipt distribution, and (iii) in terms of their labor force participation and employment rates before and after the age of first pension receipt. Whereas many repatriated ethnic Germans might have been regarded as skilled in their source countries, differences in production methods, working cultures and acquired skills between former socialist countries and market 
economies like the one of Western Germany as well as lack of recognition of educational degrees from former socialist countries, combined with language problems, limited the value of the skills brought by repatriated ethnic German immigrants to Germany. The attachment of the repatriated ethnic Germans to German culture varied considerably, with some people still speaking German at home, and others speaking no German at all. According to Bauer and Zimmermann (1997, p. 365), between 41 and 53\% of ethnic Germans arriving between 1989 and 1993 were enrolled in German language courses. A language test in the sending country as a prerequisite for immigration became only effective in 1997 (Bundesministerium des Innern und Bundesamt für Migration und Flüchtlinge, 2007). This test was not designed to test labor-market relevant language skills but rather to prove German ethnicity of the potential migrants.

Hence, despite of the fact that our natural experiments refer to a particular group, they at least suggest that significant changes in pension levels for low-skilled workers in either direction might mostly have redistributive consequences, without significant changes in the benefits receipt behavior of the affected workers.

The paper is structured as follows: Section 2 sketches the pension system in Germany, as well as the pension situation for repatriated ethnic Germans. Section 3 describes the pension reforms and the empirical methodology together with the principal data source, Section 4 presents the results, and Section 5 concludes the paper.

\section{Institutional background: the German public pension system and special rights for repatriated ethnic Germans}

\subsection{The German public pension system}

We briefly sketch the key features of the German pension system before explaining the particular rules pertaining to repatriated ethnic Germans. In Germany, the most important component of income in old age is the mandatory public pension insurance, which covers about $85 \%$ of workers (generally excluding civil servants, who have a separate pension 
system, and self-employed workers, who are mostly voluntarily selfinsured; Berkel and Börsch-Supan, 2004). By international comparison, this system is characterized by a high replacement rate of about 70\% (according to Börsch-Supan, 2000, p. F29; only 58\% according to Boeri and van Ours, 2008, p. 123), meaning that public pension benefits constitute by far the most important source of income for elderly Germans (over $80 \%$ of income for households headed by persons over 64 years of age; Börsch-Supan, 2000).

In the German public pension system, pension rights are usually based on the contributions made by employees and employers over the working life, which are translated into so-called 'earnings points' that reflect the employee's earnings position relative to other workers in the economy. One earnings point corresponds to the average earnings in the economy in a given calendar year. Therefore, depending on individual earnings in any given year, the individual may gain more or less than one earnings point per calendar year, depending on his or her position in the wage distribution. The pension level is calculated based on the total number of earnings points collected according to the following formula:

\section{Pension $=$ EarningsPoints $\times$ EntryFactor $\times$ PensionFactor $\times$ CurrentPensionValue}

where the number of EarningsPoints are the earnings points collected during working life; the EntryFactor equals 1 if the pension is first drawn at normal entry age, it is smaller (larger) than 1 in case of reductions (increases) for early (late) age of first pension receipt, but not if a person draws a pension under an early retirement scheme, which most individuals in our study did, in this case the entry factor remains 1 . The PensionFactor equals 1 for the old age pensions we consider here, it is less than 1 for a widow's or an orphan's pension. The CurrentPensionValue is adjusted each year based on wage developments. The natural experiments that we study in this paper led to a cut in earnings points for repatriated ethnic Germans having immigrated after a critical date, without affecting the other factors of the pension formula. 
The pension level is not necessarily a linear function of the earnings points earned during working life, which explains why the observed pension cuts in our data are smaller than the originally conceived cuts in earnings points. This is because for the cohorts studied here the German public pension insurance used to 'beef up' low pension levels by raising part of an individual's earnings points by up to $50 \%{ }^{1}$

For the cohorts we study, the German pension system was characterized by considerable flexibility concerning the age of first pension receipt, because of several early retirement schemes built into the system. The normal pension age was 65 , but under certain preconditions, some workers could receive public pension payments earlier, most notably at ages 63, 60 or even earlier (in case of disability) (Schmidt, 2014). One such scheme allowed any individual whose employment history exceeded 35 years to start drawing pensions at age 63. Other schemes allowed workers to receive pension payments as early as age 60; most particularly, the socalled 'reduced earnings capacity' scheme where workers who were administratively classified as not being 'appropriately employable' because of 'health or labor market reasons,' could draw benefits at age $60 .{ }^{2}$ Another pathway to early pension receipt at age 60 was a worker's having been unemployed for at least one year out of the previous 1.5 years after having

1 More specifically, if the average of the 'earnings points' per year of dependent employment accumulated before 1993 is below 0.75 (i.e. $75 \%$ of the average wage), these earnings points are either increased by $50 \%$ (if 1.5 times the average earnings points is less than 0.75 ) or are raised so that the average is exactly equal to 0.75 (if 1.5 times the average earnings points is more than 0.75 ). These rules imply an attenuation of any cut in earnings points that would cause the average earnings points per year of dependent employment before 1993 to fall below 0.75 for a given pension. However, because the effective pension floor depends on a person's years of social securityrelevant employment (or other activities regarded as equivalent to employment) before 1993 , there is no uniform and unconditional minimum pension.

${ }^{2}$ The eligibility criteria for such pensions were also met if no vacancies were available at the labor office for the worker's specific job description and changing to a different job type would have cost the worker an earnings loss of at least $50 \%$.

More precisely, when these criteria were met, an individual would not necessarily receive a full pension but could be awarded a reduced pension. However, during the 1990s, the underlying rules were interpreted so generously that most workers who retired because of 'reduced earnings capacity' received a full pension.

During the 1990s (our observation period), these rules were interpreted liberally enough that Berkel and Börsch-Supan (2004) term them 'soft eligibility rules'. As a result, Arnds and Bonin (2002) suggest that at that time, many individuals had at least some discretionary power to draw benefits as early as age 60 . Other possibilities for retiring before age 60 were by way of so-called 'partial retirement plans' or the disability retirement allowable at any age for sufficiently severe disabilities. In fact, under these same rules, workers could receive a pension due to 'reduced earnings capacity' even before reaching age 60 as long as they had contributed to the insurance system for at least five years and had worked three out of the last five years (Riphahn, 1997). 
contributed payments to the pension insurance for at least 8 out of the previous 10 years (Schmidt, 2014, p. 46). Individuals could also draw benefits at any age in case of severe disability. In addition, women could generally draw benefits at age 60 provided they had worked for at least 10 years since age 40 .

Starting in 1997 (i.e. after the implementation of the reforms studied here), first pension receipt ages for the early retirement schemes were increased (for pension receipt due to unemployment, this started in 1997, for those with an employment history of 35 years or over and for women, this started in 2000). To ease to transition to the higher ages of first pension receipt in these early retirement schemes, workers could still draw a pension at the former earlier age thresholds, but in this case they now faced a $3.6 \%$ reduction in the entry factor per year $(0.3 \%$ per month) for earlier pension receipt. Workers continuing to work after the normal retirement age gain a $6 \%$ increase in the entry factor per year of later pension receipt. This is a rare event, however, because most collective bargaining contracts force people to quit their jobs at the normal retirement age. Besides, these reductions and increases were less than the actuarially neutral amounts (Arnds and Bonin, 2002; Börsch-Supan and Schnabel, 1998; Börsch-Supan, 2000; Queisser and Whitehouse, 2006). Note that before 1997, there were even no such reductions in the entry factor for earlier pension receipt, the idea being that such earlier pension receipt was based on a precondition (35 years' employment history, 'not appropriately employable', unemployed, being female) qualifying for an early retirement scheme. As we will see below, most of the people in our sample started to draw pensions before age 65 and thus have managed to qualify for such a scheme. As shown in Queisser and Whitehouse (2006, p. 29f.), most OECD countries' pension systems provide incentives for earlier retirement in the sense that the adjustments made for earlier and later pension receipt are below the actuarially neutral levels.

An important precondition to qualify for one of those early retirement schemes (at ages 60 and 63) is that workers do indeed retire: the complete pension is withdrawn if people work in the labor market and earn more than "marginal earnings", the lower bound for social security contributions, which was 390 deutschmarks per month until 1996, €400 in 
2008 (the year for which our data file was extracted) and is $€ 450$ per month today (compare that to Liebman, Luttmer, and Seif's (2009, p. 1212) definition of retirement which sets a threshold of $\$ 2500$ per year). ${ }^{3}$ Once people reach the normal retirement age of 65 (at the time), however, there is no limit any more to labor market earnings while receiving a full pension.

\subsection{Repatriated ethnic Germans}

In this study, we evaluate a population that was affected by large cuts in pension rights; namely, repatriated ethnic Germans (Aussiedler and Spätaussiedler) and their spouses who migrated with them and up to the end of 1992 had similar pension rights. Ethnic German immigration into (West) Germany was governed by a "right-of-return" law and substantial in numbers: the German Federal Ministry of the Interior reports that between 1950 and 1999 more than 4 million people migrated under this scheme to Germany, of which about 2.7 million arrived between 1987 and 1999. During this latter period, about 1.8 million came from the former Soviet Union, more than 600 thousand from Poland and more than 200 thousand from Romania. Bauer and Zimmerman (1995), Dietz (1999) and Krieger, Kampen, and Paulsen (2006) have further information on ethnic German migration into Germany with a focus on labor market integration, migrant networks and the situation of migrants from the former Soviet Union, respectively. Dietz (1999) describe changes in laws governing ethnic German immigration. None of these laws affected treatment and control groups as defined in this study differentially as the law changes were not concurrent with the immigration cutoff dates we use to define treatment or control groups and did also not overlap with our sampling windows defined on immigration date: according to Bundesministerium des Innern und Bundesamt für Migration und Flüchtlinge (2007), the new language test to be passed in the sending country became only effective in 1997. This change was based on a headnote issued by the Federal Administrative Court (Bundesverwaltungsgericht) in November 1996 stating that active usage of

\footnotetext{
${ }^{3}$ It is possible to draw only "partial benefits", that is a third, a half or two thirds of the benefit level (Schmidt, 2014, Chapter 8). In this case, the earnings thresholds are correspondingly higher. However, this is not important empirically as not even half a percent of repatriated ethnic Germans aged between 60 and 65 in our data make use of this possibility.
} 
the German language was a key indicator for being an ethnic German. ${ }^{4}$ However, as both treatment and control groups in each of our two natural experiments immigrated to Germany before 1997, none of the persons in our samples were affected by this ruling. What is nevertheless worth noting is that, as of January $1^{\text {st }} 1993$, a new law made it difficult for people from source countries other than the former Soviet Union to immigrate to Germany as repatriated ethnic Germans. Hence the sample for the second natural experiment that we analyze is almost exclusively made up of immigrants from the former Soviet Union.

\subsection{Pensions for repatriated ethnic Germans}

Given that many repatriated ethnic Germans spent large parts of their working lives outside of Germany without paying contributions to the German public pension insurance, the Alien Pension Law (Fremdrentengesetz, FRG) acknowledges the period of employment in the previous country of residence (e.g. Soviet Union) exactly as if the individual had worked in the same occupation in Germany. Based on this recognition, it grants repatriated ethnic Germans generous pension rights. Hence, an ethnic German coming to Germany at age 65 after having worked in the Soviet Union for 40 years could go straight into retirement and receive a full pension just like a German-born individual who had worked in Germany for 40 years in the same type of job. Pension receipt earlier than 65 (i.e. at age 63, 60, or earlier) was similarly possible, because the same rules applied to repatriated ethnic Germans as were relevant for native Germans: time worked in the source country counted just like time worked in Germany for application of the rules outlined in Section 2.1.

After the fall of the Iron Curtain, a continuous wave of immigration from the former socialist countries led to a significant drain on the pension system because repatriated ethnic Germans (and East Germans) could receive pensions without ever having paid into the system. As a consequence, a set of reforms during the 1990s cut these repatriated ethnic Germans' pensions.

\footnotetext{
${ }^{4}$ The headnote can be found at https://www.jurion.de/de/document/show/0:125825,0/
} 
In the research design we apply, the repatriated ethnic Germans studied in this paper immigrated mostly at a relatively high age (55 and older), and thus spent most of their working lives outside Germany. As a result, their pension rights, rather than being based on actual contributions to the system, were mostly calculated by type and length of employment in the source country. The reforms we investigate that involve cuts in these pension rights, therefore, translate into large reductions of the repatriated immigrants' total pension rights.

\section{Pension reforms for repatriated ethnic Germans and a regression discontinuity design based on administrative data}

During the 1990s, repatriated ethnic Germans effectively faced major cuts in the pension rights they had accumulated outside Germany. In order to exploit these pension reforms as natural experiments that allow estimation of workers' reactions to unexpected cuts in pension benefits, we first briefly describe both the reforms and the corresponding administrative data. More detailed descriptions of the reforms are provided in German by both Polster (1990, 1992, 1997) and Heller (1997).

Our administrative data are taken from the Federal German Pension Insurance (Deutsche Rentenversicherung Bund, DRV-Bund), the mandatory state pension system for most German workers, which began providing access to a sample of its administrative data in 2005. We obtained remote access to the complete population of pension data on repatriated ethnic Germans for the calendar year 2008 (Versichertenrentenbestand 2008 FDZ-RV SUF Demografie Puhani Tabbert), the only year for which date of immigration (accurate to the day) - a necessary variable for our regression discontinuity analyses - was available.

These administrative pension data provide personal information on the entire population of repatriated ethnic Germans who retired before 2008 and were still alive in 2008. The data include variables such as the pension level in euros, year and month of first pension receipt, individual's age, date 
of immigration into Germany, and source country. Unfortunately, however, they include no additional socioeconomic characteristics. We must also exclude from the sample repatriated ethnic Germans who immigrated from Poland. First, this is because regulations of the Polish-German Social Security Agreement of 1975 prevented workers from Poland from being affected by any of the two natural experiments analyzed here. Second, probably because the immigration date of repatriated ethnic Germans from Poland did not matter for the calculation of their pension, the immigration date variable had many missing or implausible values for this group, which means this group is not well suited as a control group, either. Third, the number of people immigrating from Poland was at a very low level from 1991 onwards (see Figure A2). Hence, the sample sizes for the cohorts we consider are too small for immigrants from Poland to act as a control at least in the second natural experiment.

In the following, we describe the two reforms that provide the natural experiments analyzed in this study. Some complications arise due to a succession of reforms, which we can address by defining appropriate samples by immigration and birth cohort. Figure 1 therefore provides a timeline with a description of the samples corresponding to each reform.

Natural Experiment 1: On July 25, 1991, earnings points acquired abroad were cut by $30 \%$ for all repatriated ethnic Germans who had immigrated on January 1, 1991 or later (according to RentenÜberleitungsgesetz, TÜG, Art. 14,20a and Art. 15). Due to the nonlinear relationship between earnings points and pensions, actual pensions were reduced by about 7\%, which is at the low end of the $13 \%$ and the $7-10 \%$ reported for the Social Security Notch in the United States by Krueger and Pischke (1992) and Snyder and Evans (2006) using slightly different evaluation designs, respectively. Because the legislation was passed after the date of immigration, it amounted to an ex-post reduction in pension rights. Hence, the effect of the reform can be evaluated using a regression discontinuity design that compares the first pension receipt behavior of immigrants arriving shortly before and after January 11991 . Because the $1^{\text {st }}$ of January is often a date when new laws or regulations are implemented, we checked whether there were any other rule changes affecting the budget constraint of immigrants arriving after that date: we found no such changes. 
The oldest cohorts in our estimation samples are individuals who turned 60 in 1992 (i.e. cohorts born on or after January 1 1932, who were thus 76 years of age when observed in 2008), and had not yet reached an age when pension receipt was easily possible when the reform was implemented in 1991. The youngest cohorts are individuals born in March 1936 (who were 72 years of age in 2008) because the pension receipt behavior of cohorts younger than these was - irrespective of their immigration date - potentially affected by another reform that occurred in 1996.

As part of the regression discontinuity design implementation, we use the immigration date to define a sample that is a subset of the population of repatriated ethnic Germans in these birth cohorts. This subset is restricted to individuals who immigrated between July 1990 and June 1991. Those who immigrated between January and June 1991 comprise the treatment group and those who immigrated between July and December 1990 make up the control group. Two additional discontinuity samples use tighter immigration date windows around the cutoff: workers who immigrated between October 1990 and March 1991 (a 6-month window) and those who immigrated in December 1990 or January 1991 (a 2-month window). Although our administrative data contain the population of repatriated ethnic German pensioners, the sample restrictions by cohort and immigration date leave us with sample sizes of 2,346 (treated) and 3,613 (control), 1,188 (treated) and 1,386 (control), and 350 (treated) and 503 (control) persons for the three regression discontinuity samples, respectively (see Table 1). We do, however, have to rely on the regression discontinuity design as an identification strategy for lack of sufficient socio-economic control variables in the administrative data.

When evaluating Natural Experiment 1, we also censor the first pension receipt date relative to April 1 1996, because in spring 1996, the government starting to discuss and in September finally implemented plans to cut pensions for workers starting to draw benefits after October 1 1996), so that strategic behavior may have occurred to avoid this cut. Thus, in an attempt to isolate the effects of Natural Experiment 1, we remain conservative and censor first pension receipt date observations for all individuals who had received their first pension after the beginning of April 
1996, which results in the censoring of about a fifth of our estimation sample's first pension receipt ages. Tobit estimates will take account of the censoring.

Natural Experiment 2: On September 25 1996, an upper bound for earnings points (acquired abroad) was introduced for all repatriated ethnic Germans who immigrated after May 61996 (according to the Wachstumsund Beschäftigungsförderungsgesetz, WFG, Art. 3 and Art. 4, September 25 1996). The limit was 25 earnings points, which, as shown below, effectively amounted to a reduction in actual pensions of around $18 \%$, which is somewhat higher than the number reported for the Social Security Notch analyzed by Krueger and Pischke (1992) and Snyder and Evans (2006). ${ }^{5}$ The causal effect of the cut in pension rights on first pension receipt behavior can thus be derived using a regression discontinuity design as long as those immigrating just before versus just after the cutoff date do not differ systematically on other characteristics.

In order to avoid confounding Natural Experiment 2 with another reform that cut pensions for workers starting to draw benefits after October 1 1996, we want to consider only workers who turned 60 in September 1996 or later for Natural Experiment 2 - that is, the cohorts born on or after September 1 1936. We thereby minimize the number of individuals who could strategically draw benefits before October 11996 to avoid another pension cut. The youngest cohorts in the sample are those born in December 1941, so that the sample for Natural Experiment 2 had about the same age at its cutoff date as the sample for Natural Experiment 1 at its respective cutoff date (Figure 1). For the analysis, the discontinuity samples consist of 12-month (immigrated between November 6 1995, and November 6 1996), 6-month (immigrated between February 61996 and August 6 1996), and 2-month (immigrated between April 6 and June 6 1996) sampling windows (with May 61996 as the cutoff date). Table 2 shows descriptive statistics for the 2,653 (treated) and 2,683 (control), 1,312 (treated) and 1,064 (control), and 459 (treated) and 448 (control) persons for the 12-month, 6-month, and 2-month regression discontinuity samples, respectively.

\footnotetext{
${ }^{5}$ The limit of 25 earnings points applied to singles, the calculation for married couples was more complicated.
} 
In implementing the regression discontinuity approach to evaluate both natural experiments, we follow Lee and Lemieux (2010, p. 318) by regressing the date of first pension receipt on a treatment indicator $D$, which equals $l$ when the day of immigration $Z$ lies beyond a critical date $c$, and the deviation of the day of immigration from the critical day $(Z-c)$ to control for heterogeneity of immigration cohorts over time. This "running variable" is also interacted with the treatment indicator $D$, which allows the slope of its effect to differ on both sides of the critical date (cutoff). The running variable $(Z-c)$ as well as its interaction $D(Z-c)$ are included as linear, quadratic, and cubic terms, depending on the specification. By including the birth date as a control variable in $X$, we effectively estimate the reform's impact on age at first pension receipt (although technically, the date of first pension receipt is the dependent variable). We also add dummy variables for source country and gender. The estimating equation is:

$$
\begin{aligned}
& Y_{i}=\alpha+\tau D_{i}+\delta_{1}\left(Z_{i}-c\right)+\delta_{2} D_{i}\left(Z_{i}-c\right)+\beta X_{i}+\varepsilon_{i}, \quad E\left[\varepsilon_{i} \mid D_{i}, X_{i}, Z_{i}\right]=0, \\
& D_{i}=1\left(Z_{i}>c\right) .
\end{aligned}
$$

1() is the indicator function, which equals 1 if the individual arrived in Germany after the critical date and is thus affected by the reform (treated) and zero otherwise (control). Because the administrative data cover so few sociodemographic characteristics, we must rely on the regression discontinuity design to identify the causal effect of pension cuts $\tau$. If the dependent variable $Y$ is the date of first pension receipt, equation (2) can be regarded as a reduced-form of an instrumental variable regression of the date of first pension receipt on the log pension level, with the instrument being the reform the indicator $D$. The corresponding first-stage regression is equation (2) with the dependent variable $Y$ being the log pension level. In the results section below, we will start by presenting the effect of the reforms on $\log$ pensions (first-stage) and date of first pension receipt (reduced form), before presenting instrumental variable estimates (where date of first pension receipt is regressed on the log pension level 
instrumented by the reform indicator $D$ ). The instrumental variable coefficients equal the reduced form divided by the first-stage coefficients.

\section{$4 \quad$ Results}

\subsection{Effect of the two pension cut reforms on age of first pension receipt}

Table 3 presents the estimation results where we pool the data for Natural Experiments 1 and 2 in order to obtain statistically more precise estimates. Separate estimates for Natural Experiments 1 and 2 are reported in Tables A1 and A2 of the Appendix.

The first half of Table 3 shows the estimated effects of the reforms on the effective pension cuts (the estimating equation is identical to equation (2), but with the dependent variable replaced by the log pension level). Whereas Model 1 includes only the date of birth, the source country, gender, and a dummy for Natural Experiment 2 as controls, Model 2 adds in linear terms for the deviation of the day of immigration from the critical day $(Z-c)$ and its interaction with the treatment indicator $D(Z-c)$ and is hence a regression discontinuity specification. Model 3 then adds in quadratic terms for the running variables $(Z-c)$ and $D(Z-c)$. Model 4 also adds cubic terms for these variables.

As shown in Table 3, the effective pension cuts generated by the two Natural Experiments are estimated to be between 9 and $16 \%$, depending on the specification. The median estimate over all 27 regression discontinuity specifications (Models 2 to 4 ) is $12 \%{ }^{6}$ The median standard error associated with these estimates is $3 \%$. Overall, the estimates are similar between men and women, but Tables A1 and A2 of the Appendix exhibit point estimates which are mostly smaller for women than for men in

\footnotetext{
${ }^{6}$ Figure A3 (Figure A5) plots individual pension levels by date of immigration for men (women) for Natural Experiments 1 (Panel A) and 2 (Panel B). The graphs illustrate the pension cuts, including the pension cap introduced with Natural Experiment 2 (Panel B), but also the significant variation in pension levels both above and below the fitted lines due to the absence of a minimum pension.
} 
Natural Experiment 1, whereas the opposite holds for Natural Experiment $2 .^{7}$

To what extent did repatriated ethnic Germans react to these pension cuts by retiring later to make up for lost income? The lower part of Table 3 shows the estimated effects of the pension cuts on the first pension receipt age in years. ${ }^{8}$ The first striking result is that none of the regression discontinuity estimates (Models 2 to 4 ) are statistically significant. The point estimates are also small ranging between earlier first benefit receipt of 0.22 years (2.6 months) and later first benefit receipt of about 0.20 years (2.4 months). The median standard error over these 27 regression discontinuity estimates is 0.17 years ( 2 months). The median estimate for the sample with men and women combined is -0.04 years (not even half a month earlier pension receipt) and has a standard error of 0.1 years (1.2 months). Full regression results for the specification with a cubic control for the running variable (Model 4) and a 12-month sampling window are reported in Table 4 . The estimated treatment of -0.08 years with a standard error of 0.14 years implies a $95 \%$-confidence interval estimate with lower bound $(-0.08-1.96 \times 0.14)=-0.35$ (minus 4.3 months) and upper bound ($0.08+1.96 \times 0.14)=0.19(2.3$ months $)$. Hence, the confidence interval does not include a large increase in the age of first benefit receipt. The separate regression discontinuity estimates for Natural Experiment 1 (shown in Table A1) and Natural Experiment 2 (Table A2) also exhibit no statistically significant effect of the pension cut reforms on the age at first pension receipt (Models 2 and 3), with point estimates again being very close to zero. The graphical presentations of the cumulative distribution functions of the log pension levels (Figures 2 and 4 for men and women, respectively) and the survivor functions of the age of first pension receipt

\footnotetext{
${ }^{7}$ Smaller pension reductions for women through Natural Experiment 1 may be attributable to the fact that women, although generally exhibiting high labor force participation rates in former socialist countries, on average have gathered fewer earnings points than men, meaning that they were more greatly affected by the rule for "beefing up" low pensions (see footnote 1). This interpretation is substantiated by Figure 4, Panel A, which shows that only women with higher pensions experienced pension cuts.

${ }^{8}$ In this table, we estimate Tobit models because individuals in the sample used to evaluate Natural Experiment 1 were also affected by a further pension cut if they decided to draw their first benefits after September 1996. In order not to confound these two reforms, we censor the date of first pension receipt at April 11996 and estimate Tobit models to take account of the censoring. As Table 1 shows, about $17 \%$ of the observations in the sample for Natural Experiment 1 are censored. In the sample used to evaluate Natural Experiment 2, in contrast, the outcome variable is never censored.
} 
(Figures 3 and 5 for men and women, respectively) also suggest that there has been no significant change in the distribution of age of first pension receipt despite of significant pension cuts..$^{9} 10$

\subsection{Instrumental variable estimates and comparison with other studies}

We have found no significant effects of the pension cut reforms on the age of first pension receipt from our regression discontinuity estimates. The regressions we have presented in Table 3 can be seen as the first stage and reduced form estimates of instrumental variable regressions of age of first pension receipt on the log pension level. In the top panel of Table 5, we report these instrumental variable estimates, whose coefficients are the corresponding reduced-form divided by the corresponding first-stage estimates in Table 3. As instrumental variable regression is "data-hungry", standard errors are comparatively large, so that we only report estimates based on the 12-month sampling window. The table only shows Model 1 (without controlling for the immigration date) and Model 2 estimates (controlling for the immigration date linearly, these are the regression discontinuity design estimates). Standard errors for smaller sampling windows and higher-order polynomials in immigration date are too large to lend themselves to meaningful interpretation.

As shown in Table 5, none of the regressions discontinuity instrumental variable estimates are statistically significant (Model 2). The point estimate when combining the male and female samples for both reforms is 0.01 years with a standard error of 0.61 . The statistical

\footnotetext{
${ }^{9}$ Individual ages of first pension receipt by date of immigration are plotted in Figures A4 and A6 for men and women, respectively.

${ }^{10}$ We also tried to produce estimates depending on the size of the effective pension cut, which requires us to calculate counterfactual pension levels for treatment and control groups. Our attempts to achieve this failed for both reforms, because in more than $70 \%$ of the observations in our sample, the earnings points were "manually" rather than "mechanically" calculated (as indicated by a variable in our data set), that is by an employee of the pension insurance rather than automatically by the pension system's data processing software. As a result, we do not have the component variables needed to simulate the pension level under both treatment and under control regimes. Although workers with higher pension levels experienced larger cuts in both reforms, as shown by Figures 2 and 4, workers with lower pension levels still faced sizeable cuts, which are statistically significant (women in Natural Experiment 1 being an exception). These cuts seem to have had virtually no effect on the distribution of age of first pension receipt, as the survivor curves in Figures 3 and 5 indicate: the confidence intervals for treatment and control groups almost always overlap.
} 
significance of two coefficients in Model 1 (which are not regression discontinuity estimates) reflects the statistical significance of the reducedform estimates in Table 3, but, as also shown in Table 3, all other reducedform estimates, that is those for the 6-month or 2-month sampling windows or those of the regression discontinuity models (Models 2 through 4) are statistically insignificant, with point estimates close to zero. Hence, there is no robust evidence for any effect of these ex-post pension cuts on age of first pension receipt.

In order to compare our results with the previous literature, we have estimated models similar to the ones of Krueger and Pischke (1992) and Danzer (2013). Krueger and Pischke (1992) estimate the effect of log social security wealth on the log odds ratio of the labor force participation rate for workers aged between 60 and 68 years of age. For the generations around the so-called "Social Security Notch", they treat social security wealth as exogenous. They do not estimate an instrumental variable model nor a regression discontinuity design. Based on the information in our administrative data on the age of first pension receipt, we calculate the share of time a worker was not receiving a pension in that same age group (as a proxy for being in the labor force, see below) and - similarly to Krueger and Pischke (1992) - we regress the log odds ratio of that share on the log pension (the percentage change of the pension level equals the percentage change of social security wealth). The coefficients of an instrumental variable regression of the log odds ratio on the instrumented log pension level are shown in the middle part of Table 5. As in Table 6 of Krueger and Pischke's (1992, p. 432) estimates, all estimates are statistically insignificant. The insignificant point estimate for men and women combined suggests that a one percent increase in the pension level decreases the odds ratio of not yet receiving a pension by $0.12 \%$, with a standard error of 0.27. Krueger and Pischke's (1992) estimate in column (3) is of opposite sign with an increase of 0.18 with the same standard error of 0.27 . Our point estimate changes to a positive 0.53 with a standard error of 0.66 when we introduce two-sided linear controls for the date of immigration in the regression discontinuity specification of Model 2. Despite of some differences in research design, our results are similar to those of Krueger and Pischke (1992) in that our reforms are associated with 
similar pension cuts $(10 \%$ or somewhat more), but do not exhibit a significant reaction in pension receipt behavior (labor supply behavior in the case of Krueger and Pischke, 1992).

The lower part of Table 5 tries to compare our results with the semielasticity reported in Danzer (2013) for Ukrainian workers, which is reported to be between 0.116 and 0.188 (both numbers are statistically significant) in his Table B1 (Danzer, 2013, p. 1079, and p. 4 of online Appendix B). Danzer (2013) reports instrumental variable results regressing a binary indicator for being retired on instrumented log income (pensions plus earnings), restricting himself to workers aged 58/59 or 61/62 for men and workers aged 53/64 or 56/57 for women). This age choice reflects the general age of first pension receipt being 60 for men and 55 for women in Ukraine. Due to the different institutional setup for pension receipt in Germany, we use the complete age sample to calculate an indicator for pension receipt at age 61 or after as a further outcome variable. This reflects that repatriated ethnic Germans have a modal first pension receipt age at age 60 (for both men and women). The semi-elasticities estimated by instrumental variable regressions in the lower part of Table 5 are statistically insignificant, with point estimates for the sample with men and women combined of 0.02 in Model 1 and 0.09 in Model 2 (regression discontinuity estimates). Hence, the estimates are somewhat lower than in Danzer (2013, Table B1 of online Appendix B), although the standard errors are larger, especially in Model 2. If one were to interpret these insignificant point estimates, they would mean that a one percent increase in pensions would lead to an increase in the probability to draw a pension at age 61 or after by 0.02 or 0.09 percentage points (i.e. by far less than one percentage point), respectively. Danzer's (2013) estimates at 0.19 for men and 0.13 for women are higher, but interpreted to be small by the author. In sum, like Krueger and Pischke (1992), but unlike Danzer (2013), we do not find statistically significant effects of pension cuts, but if we do interpret our point estimates and compare them to Danzer's (2013), we also find that these point estimates are small.

Note that other literature for the United States concludes that pension levels influence retirement behavior significantly. For example, Mastrobuoni (2009) finds that increasing the normal retirement age 
increases the actual retirement age by about half the increase in the normal retirement age. Liebman, Luttmer and Seif (2009) demonstrate that American workers react to variations in marginal benefits generated by discontinuities in the Social Security System. While these two studies investigate rather different natural experiments from ours, Snyder and Evans (2006) exploit the Social Security Notch similar to Krueger and Pischke (1992) and find a positive labor supply reaction to the cuts in pensions, mainly through increases in labor supply for workers aged 67 or older. For Russia, Jensen and Richter (2003) find positive labor supply effects for workers affected by the pensions arrears, which caused incomes to decline by about a third for the affected households. This extreme event, which drove many of the affected households into poverty and even impacted on reported calorie intakes, is, however, rather different from the decreed pension increases in Ukraine studied by Danzer (2013) or for repatriated ethnic Germans studied here.

\subsection{Pension receipt and labor supply - similarities between repatriated ethnic Germans and low-skilled Germans}

The other studies mentioned in the above paragraph use data that measure labor supply directly. In our study, the administrative data of the pension system only allow us to directly study the effect of the pension level on the age of first pension receipt, which turns out to be close to zero. Does this mean that the pension cuts had no effect on labor supply? The only information provided in the administrative pension data is whether a pensioner drew a "partial pension" because he or she was receiving more than "marginal earnings" as labor income. As mentioned in footnote 3, less than half a percent of repatriated ethnic Germans aged between 60 and 65 drew a partial pension in 2008. This suggests that for more recent cohorts of repatriated Germans, drawing benefits essentially meant retirement, because this was essentially required under the early retirement schemes mentioned in Section 2.

In order to learn more about the relationship between pension receipt and labor supply, we have to draw on alternative data sets, that is the German Socio-Economic Panel (GSOEP) and the Microcensus. Table 6 
compares the labor force status of repatriated ethnic Germans not receiving a pension with the labor force status of repatriated ethnic Germans receiving a pension. We report the same statistics for low-skilled Germans (defined to be those without apprenticeship training). For the GSOEP, we use the years 1995 to 1999 , for which we have information both on recent immigrants and on current pension receipt. We restrict ourselves to repatriated ethnic Germans having immigrated since 1988 (to obtain a larger sample than if we were to use exactly the same time frames as for the analysis of the natural experiments above) and aged 55 to 65 at the time of observation. The Microcensus did not contain information on immigration background before 2005 and so we use 2005 data on repatriated ethnic Germans who immigrated since 1990 and were aged 55 to 65 at the time of observation. The sample size in the GSOEP is smaller than in the Microcensus, so some results in Table 6 based on the GSOEP have to rely on less than 100 observations.

The results in Table 6 suggest that for both men and women, the decision to draw pension benefits implies mostly, albeit not exclusively, the decision to stop supplying labor. Using GSOEP data, we find that among repatriated ethnic German men 61(51)\% were participating (employed) in the labor market. By contrast, among repatriated ethnic German men who were receiving a pension, $2(0) \%$ were participating (employed) in the labor market. The results from the Microcensus are similar: here we find that among repatriated ethnic German men who were not receiving a pension, $88(66) \%$ were participating (employed) in the labor market whereas among those who were receiving a pension, $7(5) \%$ were participating (employed) in the labor market. Women receiving a pension also had a much lower labor force participation rate than women not receiving a pension, but those not receiving a pension had a lower labor force participation rate than men from the same age and immigration cohorts.

If both treated and control workers changing status from not receiving to receiving pensions changed their labor force status similarly to the difference between the groups reported in Table 6, then measuring labor supply based on first pension receipt would overestimate labor supply elasticities, meaning that the effects reported in Table 3 and Table 5 could be seen as upper bounds on the labor supply effects. At least in the GSOEP 
data on similar cohorts as those investigated in the administrative pension data, we find that virtually none of the repatriated ethnic Germans receiving pensions supplied any labor. This is in line with the administrative regulations of the early retirement schemes described in Section 2. Hence, as we find that the pension cuts did not increase the date of first pension receipt, we might also conclude that they did not defer the age of retirement, unless the pension cuts had an effect on labor supply before the date of first pension receipt (which we cannot test with the available data).

Apart from being potentially informative on (the absence of) labor supply effects of pension cuts for repatriated ethnic Germans, our estimation results may also be informative about low-skilled Germans in general. Table 6 shows that the labor force status of repatriated ethnic Germans with and without pension receipt is similar to the corresponding labor force status of low-skilled Germans, especially for men. In addition, Figure 6 exhibits the survivor functions for age of first pension receipt for repatriated ethnic Germans, low-skilled and skilled Germans for people born between 1932 and 1936, based on administrative pension data. Especially for men, the age of first pension receipt distribution is very similar for repatriated ethnic Germans and low-skilled Germans, with both groups having a modal age of first pension receipt of 60. By contrast, the age of first pension receipt distribution is distinctly different for skilled Germans, who are much more likely to first draw their pensions at higher ages than 60 , namely 63 or 65 .

Table 7, based on Microcensus data, shows that occupational distributions of repatriated ethnic Germans are similar to the distributions of low-skilled Germans in the same group 55-65, but distinct from the occupational distribution of skilled Germans. In particular, $54 \%$ of the male repatriated ethnic Germans aged 55-65 work in blue-collar jobs, which is almost identical to the $56 \%$ for low-skilled male German workers aged 5565. Contrast these numbers with the much lower figure of $26 \%$ for all German workers in that age group. 


\section{Conclusions}

This paper is one of the very few studies to investigate large (about $12 \%$ ) exogenous cuts in pensions. We analyze two natural experiments involving ex post cuts in pension levels, but find no reaction in terms of deferring the age of first pension benefit receipt. As most people in our sample started to draw pensions under an early retirement scheme, German regulations forced them to reduce their labor supply significantly when starting to draw pensions. The pension cut reforms analyzed here only affected repatriated ethnic Germans, most of whom arrived in Germany from the former Soviet Union or from Romania (immigrants from Poland being exempted from these reforms). We show that the repatriated ethnic Germans analyzed here resemble low-skilled German workers (i) in their job distributions when working in Germany, (ii) in their age of first pension receipt distributions, and (iii) in both their probabilities to participate and to be employed in the labor market, both before and after their first pension benefit receipt.

Our findings thus suggest that repatriated ethnic Germans, and possibly also low-skilled workers in general as they show similarities with the former group, are bogged down in a "corner solution" of retiring as early as possible, one in which the price of leisure is so low that even the comparatively large pension cuts analyzed here provide no incentives to work longer. As illustrated in Queisser and Whitehouse (2006, p. 29), many OECD countries provide incentives for early retirement by not reducing pensions actuarially in case of early pension receipt. The German early retirement schemes are one such example, so that quitting the labor market as early as possible seems the optimal choice. This finding is consistent with descriptive evidence on low effective retirement ages in many continental European economies as reported in OECD (2013, p. 129).

One major policy implication of this finding is that even significant decreases or increases in the pension level - for example, of $12 \%$ as analyzed here - have virtually no incentive effect in terms of the age of first benefit receipt and thus have predominantly distributional consequences (assuming that benefit receipt mostly implies retirement and that the intensive labor supply elasticity is low). Although Danzer (2013) finds that 
labor supply effects of pension changes in Ukraine work against the distributional effects, the latter effects still dominate the former given the small elasticity estimates. There thus seems ample scope for redistribution in both directions through changes in the pension level.

The two factors used by Krueger and Pischke (1992) to explain their findings for the U.S. - private pensions or private wealth substituting for pensions - cannot explain the absence of any pension cut effect on the age of first pension receipt in our study. Having returned to Germany from former socialist countries, the repatriates we analyze can safely be expected to have had almost no private wealth or company pension. Rather, their alternative income sources are their spouse's pension/earnings (most women worked in socialist countries) or support from their children. Although a social welfare program for the elderly was in place when the individuals in our sample started to draw benefits, the Federal Statistical Office and the German Parliament report that take-up rates were generally low because many elderly shied away from asking their children - who were required by law to support parents in need - to disclose their financial situation (Statistisches Bundesamt 2008; Deutscher Bundestag 2001). ${ }^{11}$

\section{References}

Arnds, P., Bonin, H., 2002. Frühverrentung in Deutschland: Ökonomische Anreize und institutionelle Strukturen. IZA Discussion Paper No. 666.

Bauer, T., Zimmermann, K.F., 1995. Arbeitslosigkeit und Löhne von Ausund Übersiedlern. in: Steiner, V. and Bellmann, L. (eds): Mikroökonomik des Arbeitsmarktes, Institut für Arbeitsmarkt- und Berufsforschung der Bundesanstalt für Arbeit, Nürnberg.

\footnotetext{
${ }^{11}$ ISG (1999) also reports that the share of pensioners overall who received social welfare in 1997 was only $1.3 \%$ and for repatriated ethnic Germans who migrated before 1993 , that figure was as low as $3.3 \%$ (ISG, 2002). There is no separate figure for repatriated ethnic Germans who are pensioners. However, it is important to note that when the individuals in our sample retired, eligibility determination for social security took into account both spouse's and children's income, as well as other income sources. Hence although pensions for people in our sample were generally low, high labor force participation rates for both men and women in former socialist countries generally resulted in "family pensions" above the subsistence level. Based on these observations, the pension cuts analyzed here could not simply have been cushioned by higher social welfare receipt.
} 
Bauer, T., Zimmermann, K.F., 1997. Unemployment and wages of ethnic Germans. Quarterly Review of Economics and Finance 37, 361377.

Berkel, B., Börsch-Supan, A., 2004. Pension reform in Germany: the impact on retirement decisions. FinanzArchiv 60, 393-421.

Boeri, T., van Ours, J., 2008. The economics of imperfect labor markets. Princeton University Press, Princeton, NJ.

Börsch-Supan, A., 2000. A model under siege: a case study of the German retirement insurance system. Economic Journal 110, F24-F45.

Börsch-Supan, A., Schnabel, R., 1998. Social security and declining laborforce participation in Germany. American Economic Review Papers and Proceedings 88, 173-178.

Bundesministerium des Innern und Bundesamt für Migration und Flüchtlinge, 2007. Migrationsbericht des Bundesamtes für Migration und Flüchtlinge im Auftrag des Bundesregierung, Nürnberg, www.bmi.bund.de.

Card, D., Chetty, R., Weber, A., 2007. Cash-on-hand and competing models of intertemporal behavior: new evidence from the labor market. Quarterly Journal of Economics 491, 1511-1560.

Danzer, A.M., 2013. Benefit generosity and the income effect on labour supply: quasi-experimental evidence. Economic Journal 123, 1059-1084.

Deutscher Bundestag, 2001. Bundestagsdrucksache 14/5150, Berlin.

Dietz, B., 1999. Ethnic German immigration from Eastern Europe and the former Soviet Union to Germany: the effects of migrant networks, IZA Discussion Paper No. 68, Bonn.

Heller, B., 1997. Wachstums- und Beschäftigungsförderungsgesetz: Die Änderungen im Versicherungs- und Rentenrecht. Die Angestelltenversicherung 44, 1-7.

ISG Institut für Sozialforschung und Gesellschaftspolitik, 1999. Grundinformationen und Daten zur Sozialhilfe im Auftrag des Bundesministeriums für Arbeit und Sozialordnung, Cologne.

ISG Institut für Sozialforschung und Gesellschaftspolitik, 2002. Aussiedlerinnen und Aussiedler in der Sozialhilfe. Studie im Auftrag des Bundesministeriums für Arbeit und Sozialordnung, Endbericht, Cologne.

Jensen, R.T., Richter, K., 2003. The health implications of social security failure: evidence from the Russian pension crisis. Journal of Public Economics 88, 209-236. 
Krieger, V., Kampen, H, Paulsen N., 2006. Deutsche aus Russland gestern und heute, 7. Auflage, Stuttgart: Landsmannschaft der Deutschen aus Russland.

Krueger, A.B., Pischke, J.-S., 1992. The effect of social security on labor supply: a cohort analysis of the notch generation. Journal of Labor Economics 10, 4120-4437.

Lee, D.S., Lemieux, Th., 2010. Regression Discontinuity Designs in Economics, Journal of Economic Literature 48, 281-355.

Liebman, J.B., Luttmer E.F.P., Seif, D.G., 2009. Labor supply responses to marginal Social Security benefits: Evidence from discontinuities. Journal of Public Economics 93, 1208-1223.

Mastrobuoni, G., 2009. Labor supply effects of the recent social security benefit cuts: Empirical estimates using cohort discontinuities. Journal of Public Economics 93, 1224-1233.

OECD, 2011. Pensions at a glance 2011: retirement-income systems in OECD and G20 countries, Paris, OECD Publishing.

OECD, 2013. Pensions at a glance 2013: OECD and G20 Indicators, Paris, OECD Publishing.

Polster, A., 1990. Änderung des Fremdrenten - und Auslandsrechts durch das Gesetz zum Staatsvertrag. Deutsche Rentenversicherung, 508517.

Polster, A., 1992. Erneute Änderung des Fremdrentenrechts. Deutsche Rentenversicherung, 2-3, 165-174.

Polster, A., 1997. Erneute Änderung im Fremdrentenbereich. Deutsche Rentenversicherung, 1-2, 79-93.

Queisser, M., Whitehouse, E., 2006. Neutral or fair? Actuarial concepts and pension-system design, OECD Social, Employment and Migration Working Papers No. 40, Paris.

Riphahn, R. T., 1997. Disability retirement and unemployment - substitute pathways for labour force exit? An empirical test for the case of Germany. Applied Economics 29, 551-561.

Schmidt, H., 2014. Rente wegen Alters, Studientext Nr. 16, Deutsche Rentenversicherung Bund, Berlin.

Snyder, S.E., Evans, W.N., 2006,. The effect of income on mortality: evidence from the social security notch, Review of Economics and Statistics 88, 482-495.

Statistisches Bundesamt, 2008. Ergebnisse der Sozialhilfestatistik 2006, Wiesbaden. 


\section{Tables and Figures}

Table 1

Sample means for Natural Experiment 1 - treatment and control groups in different discontinuity samples: men and women combined.

\begin{tabular}{lcccccc}
\hline & \multicolumn{2}{c}{ 12-month window } & \multicolumn{2}{c}{ 6-month window } & \multicolumn{2}{c}{ 2-month window } \\
\cline { 2 - 7 } & Treatment & Control & Treatment & Control & Treatment & Control \\
\hline Age of first pension receipt & 60.4 & 60.5 & 60.3 & 60.3 & 60.1 & 60.2 \\
& $(1.84)$ & $(2.11)$ & $(1.89)$ & $(1.94)$ & $(1.71)$ & $(1.89)$ \\
Date of first pension receipt & 1994.6 & 1994.7 & 1994.6 & 1994.5 & 1994.3 & 1994.4 \\
& $(2.17)$ & $(2.42)$ & $(2.19)$ & $(2.23)$ & $(2.09)$ & $(2.23)$ \\
Share - censored & 0.17 & 0.23 & 0.17 & 0.17 & 0.15 & 0.17 \\
Pension payment in $€$ & 723.0 & 736.3 & 725.9 & 773.6 & 751.4 & 792.7 \\
& $(185.8)$ & $(233.3)$ & $(182.0)$ & $(215.4)$ & $(168.9)$ & $(223.0)$ \\
Date of birth & 1934.2 & 1934.2 & 1934.3 & 1934.2 & 1934.2 & 1934.2 \\
& $(1.25)$ & $(1.25)$ & $(1.23)$ & $(1.26)$ & $(1.26)$ & $(1.31)$ \\
From Romania & 0.24 & 0.44 & 0.23 & 0.26 & 0.18 & 0.18 \\
From the former USSR & 0.72 & 0.53 & 0.73 & 0.71 & 0.79 & 0.78 \\
From another country & 0.04 & 0.03 & 0.03 & 0.03 & 0.03 & 0.04 \\
Share male & 0.43 & 0.43 & 0.43 & 0.42 & 0.43 & 0.40 \\
\hline Number of observations & 2,346 & 3,613 & 1,188 & 1,386 & 350 & 503 \\
\hline
\end{tabular}

Note: Standard deviations in parentheses.

Source: Administrative German pension data (Versichertenrentenbestand 2008 FDZ-RV SUF Demografie Puhani Tabbert); authors' calculations.

Table 2

Sample means for Natural Experiment 2 - treatment and control groups in different discontinuity samples: men and women combined.

\begin{tabular}{lcccccc}
\hline & \multicolumn{2}{c}{ 12-month window } & \multicolumn{2}{c}{ 6-month window } & \multicolumn{2}{c}{ 2-month window } \\
\cline { 2 - 7 } & Treatment & Control & Treatment & Control & Treatment & Control \\
\hline Age of first pension receipt & 60.5 & 60.4 & 60.5 & 60.5 & 60.5 & 60.5 \\
& $(1.59)$ & $(1.75)$ & $(1.60)$ & $(1.75)$ & $(1.59)$ & $(1.79)$ \\
Date of first pension receipt & 1999.7 & 1999.6 & 1999.6 & 1999.7 & 1999.5 & 1999.8 \\
& $(2.26)$ & $(2.43)$ & $(2.27)$ & $(2.41)$ & $(2.24)$ & $(2.47)$ \\
Pension payment in $€$ & 503.8 & 617.7 & 504.1 & 596.8 & 493.1 & 586.4 \\
& $(93.4)$ & $(140.6)$ & $(94.8)$ & $(134.8)$ & $(97.7)$ & $(135.2)$ \\
Date of birth & 1939.2 & 1939.2 & 1939.1 & 1939.2 & 1939.1 & 1939.4 \\
From Romania & $(1.49)$ & $(1.49)$ & $(1.48)$ & $(1.49)$ & $(1.46)$ & $(1.50)$ \\
From the former USSR & 0.04 & 0.05 & 0.04 & 0.05 & 0.06 & 0.04 \\
From another country & 0.94 & 0.93 & 0.94 & 0.93 & 0.92 & 0.94 \\
Share male & 0.02 & 0.02 & 0.01 & 0.02 & 0.01 & 0.02 \\
\hline Number of observations & 0.42 & 0.41 & 0.42 & 0.41 & 0.42 & 0.40 \\
\hline
\end{tabular}

Note: Standard deviations in parentheses.

Source: Administrative German pension data (Versichertenrentenbestand 2008 FDZ-RV SUF Demografie Puhani Tabbert); authors' calculations. 
Table 3

Estimation results pooling data for Natural Experiments 1 and 2.

\begin{tabular}{|c|c|c|c|c|}
\hline & Model 1 & Model 2 & Model 3 & Model 4 \\
\hline \multicolumn{5}{|c|}{ Estimated change in log pension wealth } \\
\hline \multicolumn{5}{|c|}{$M e n-O L S$} \\
\hline 12-month sampling window & $-0.14 * * *$ & $-0.09 * * *$ & $-0.10 * * *$ & $-0.11 * * *$ \\
\hline$n=4,771$ & $(0.01)$ & $(0.02)$ & $(0.03)$ & $(0.03)$ \\
\hline 6-monthsampling window & $-0.11 * * *$ & $-0.10 * * *$ & $-0.11 * * *$ & $-0.16 * * *$ \\
\hline$n=2,077$ & $(0.01)$ & $(0.02)$ & $(0.03)$ & $(0.04)$ \\
\hline 2-month sampling window & $-0.10 * * *$ & $-0.14 * * *$ & $-0.15 * * *$ & $-0.12 *$ \\
\hline$n=724$ & $(0.03)$ & $(0.03)$ & $(0.05)$ & $(0.07)$ \\
\hline \multicolumn{5}{|l|}{ Women - OLS } \\
\hline 12-month sampling window & $-0.13 * * *$ & $-0.12 * * *$ & $-0.12 * * *$ & $-0.11 * * *$ \\
\hline$n=6,524$ & $(0.01)$ & $(0.02)$ & $(0.03)$ & $(0.04)$ \\
\hline 6-month sampling window & $-0.12 * * *$ & $-0.12 * * *$ & $-0.11 * * *$ & $-0.13 * *$ \\
\hline$n=2,873$ & $(0.01)$ & $(0.03)$ & $(0.04)$ & $(0.05)$ \\
\hline 2-month sampling window & $-0.11 * * *$ & $-0.12 * * *$ & $-0.15 * *$ & -0.09 \\
\hline$n=1,036$ & $(0.02)$ & $(0.04)$ & $(0.07)$ & $(0.10)$ \\
\hline \multicolumn{5}{|l|}{ Men and women - OLS } \\
\hline 12-month sampling window & $-0.13 * * *$ & $-0.11 * * *$ & $-0.11 * * *$ & $-0.12 * * *$ \\
\hline$n=11,295$ & $(0.01)$ & $(0.01)$ & $(0.02)$ & $(0.03)$ \\
\hline 6-month sampling window & $-0.12 * * *$ & $-0.11 * * *$ & $-0.12 * * *$ & $-0.15 * * *$ \\
\hline$n=4,950$ & $(0.01)$ & $(0.02)$ & $(0.03)$ & $(0.04)$ \\
\hline 2-month sampling window & $-0.11 * * *$ & $-0.14 * * *$ & $-0.16 * * *$ & $-0.11 *$ \\
\hline$n=1,760$ & $(0.02)$ & $(0.03)$ & $(0.05)$ & $(0.07)$ \\
\hline \multicolumn{5}{|c|}{ Estimated effect [in years] of pension cuts on age of first pension receipt } \\
\hline \multicolumn{5}{|c|}{ Men - Tobit } \\
\hline 12-month sampling window & -0.03 & -0.07 & -0.10 & 0.01 \\
\hline$n=4,771$ & $(0.06)$ & $(0.12)$ & $(0.17)$ & $(0.24)$ \\
\hline 6-month sampling window & -0.02 & -0.16 & 0.13 & 0.17 \\
\hline$n=2,077$ & $(0.08)$ & $(0.16)$ & $(0.25)$ & $(0.34)$ \\
\hline 2-month sampling window & -0.05 & 0.20 & -0.22 & 0.12 \\
\hline$n=724$ & $(0.13)$ & $(0.27)$ & $(0.42)$ & $(0.57)$ \\
\hline \multicolumn{5}{|l|}{ Women - Tobit } \\
\hline 12-month sampling window & $0.12 * * *$ & 0.05 & 0.04 & -0.07 \\
\hline$n=6,524$ & $(0.03)$ & $(0.07)$ & $(0.11)$ & $(0.15)$ \\
\hline 6-month sampling window & $0.09 *$ & 0.03 & -0.05 & -0.21 \\
\hline$n=2,873$ & $(0.05)$ & $(0.11)$ & $(0.17)$ & $(0.23)$ \\
\hline 2-month sampling window & -0.01 & -0.03 & -0.02 & -0.01 \\
\hline$n=1,036$ & $(0.09)$ & $(0.19)$ & $(0.31)$ & $(0.44)$ \\
\hline \multicolumn{5}{|l|}{ Men and women - Tobit } \\
\hline 12-month sampling window & $0.06^{*}$ & 0.00 & -0.04 & -0.08 \\
\hline$n=11,295$ & $(0.03)$ & $(0.07)$ & $(0.10)$ & $(0.14)$ \\
\hline 6-month sampling window & 0.05 & -0.07 & -0.01 & -0.09 \\
\hline$n=4,950$ & $(0.05)$ & $(0.09)$ & $(0.14)$ & $(0.20)$ \\
\hline 2-month sampling window & -0.04 & 0.02 & -0.16 & 0.00 \\
\hline$n=1,760$ & $(0.08)$ & $(0.16)$ & $(0.25)$ & $(0.36)$ \\
\hline
\end{tabular}

Note: Model 1 controls for date of birth, source country, a dummy for Natural Experiment 2 and a gender dummy if applicable, Model 2 also controls for immigration date (discontinuity design estimator), and Model 3 additionally controls for the square of the immigration date (discontinuity design estimator), Model 4 additionally controls for the cube of the immigration date (discontinuity design estimator). Standard errors in parentheses. *** significant at the $1 \%$ level; ** significant at the $5 \%$ level; * significant at the $10 \%$ level.

Source: Administrative German pension data (Versichertenrentenbestand 2008 FDZ-RV SUF Demografie Puhani Tabbert); authors' calculations. 
Table 4

Full regression results pooling data for Natural Experiments 1 and 2. Men and women combined. 12-month window. Cubic control for day of immigration.

\begin{tabular}{lcc}
\hline Dependent variable: date of first pension receipt & Coeff. & Std. err. \\
[1 unit equals 1 year] & -0.08 & $(0.14)$ \\
\hline Treatment & 0.55 & $(0.53)$ \\
Day of immigration & -0.57 & $(0.69)$ \\
Day of immigration * natural experiment 2 & 0.86 & $(0.66)$ \\
Square of day of immigration & -0.98 & $(0.90)$ \\
Square of day of immigration * natural experiment 2 & 0.30 & $(0.23)$ \\
Cube of day of immigration & -0.33 & $(0.33)$ \\
Cube of day of immigration * natural experiment 2 & -0.48 & $(0.92)$ \\
Treatment * day of immigration & -0.68 & $(0.94)$ \\
Treatment * square of day of immigration & -0.41 & $(0.40)$ \\
Treatment * cube of day of immigration & 0.75 & $(1.25)$ \\
Treatment * day of immigration * natural experiment 2 & 0.58 & $(1.01)$ \\
Treatment * square of day of immigration * natural experiment 2 & 0.49 & $(0.55)$ \\
Treatment * cube of day of immigration * natural experiment 2 & $-0.49 * * *$ & $(0.15)$ \\
Natural experiment 2 & $1.01^{* * *}$ & $(0.01)$ \\
Date of birth [years] & $-0.65 * * *$ & $(0.10)$ \\
From ex-USSR & 0.12 & $(0.11)$ \\
From Romania & $0.56^{* * *}$ & $(0.03)$ \\
Male & $149.49 * * *$ & $(22.18)$ \\
Constant & $1.64^{* * *}$ & $(0.01)$ \\
\hline Sigma & $-27,719.5$ & \\
log likelihood (constant only) & $-20,392.8$ & \\
log likelihood (model) & 11,295 & \\
Number of observations & 1,209 & \\
Number of right-censored observations & & \\
\hline Note: The treatment effect is estimated in units of years (but measured to the day). $* * *$ significant at the 1\% \\
level; ** significant at the 5\% level; * significant at the 10\% level. \\
Source: Administrative German pension data (Versichertenrentenbestand 2008 FDZ-RV SUF Demografie \\
Puhani Tabbert); authors' calculations. & &
\end{tabular}




\section{Table 5}

Instrumental variable estimation results for different outcome variables. Pooling data for Natural Experiments 1 and 2.

\begin{tabular}{lcc}
\hline \multicolumn{2}{l}{ IV Tobit estimates (Dependent variable: date of first pension receipt) } & Model 2 \\
Men & & \\
12-month sampling window & 0.18 & 0.75 \\
$n=4,771$ & $(0.41)$ & $(1.23)$ \\
Women & & \\
12-month sampling window & $-0.96^{* * *}$ & -0.43 \\
$n=6,524$ & $(0.28)$ & $(0.62)$ \\
& & \\
Men and women & & \\
12-month sampling window & $-0.46^{*}$ & 0.01 \\
$n=11,295$ & $(0.25)$ & $(0.61)$
\end{tabular}

IV Logit (Dependent variable: log odds ratio of not yet receiving a pension) Men

12-month sampling window

$n=3,957$

Women

12-month sampling window

$n=5,273$

Men and women

12-month sampling window $\quad-0.12 \quad 0.53$

$n=9,232$

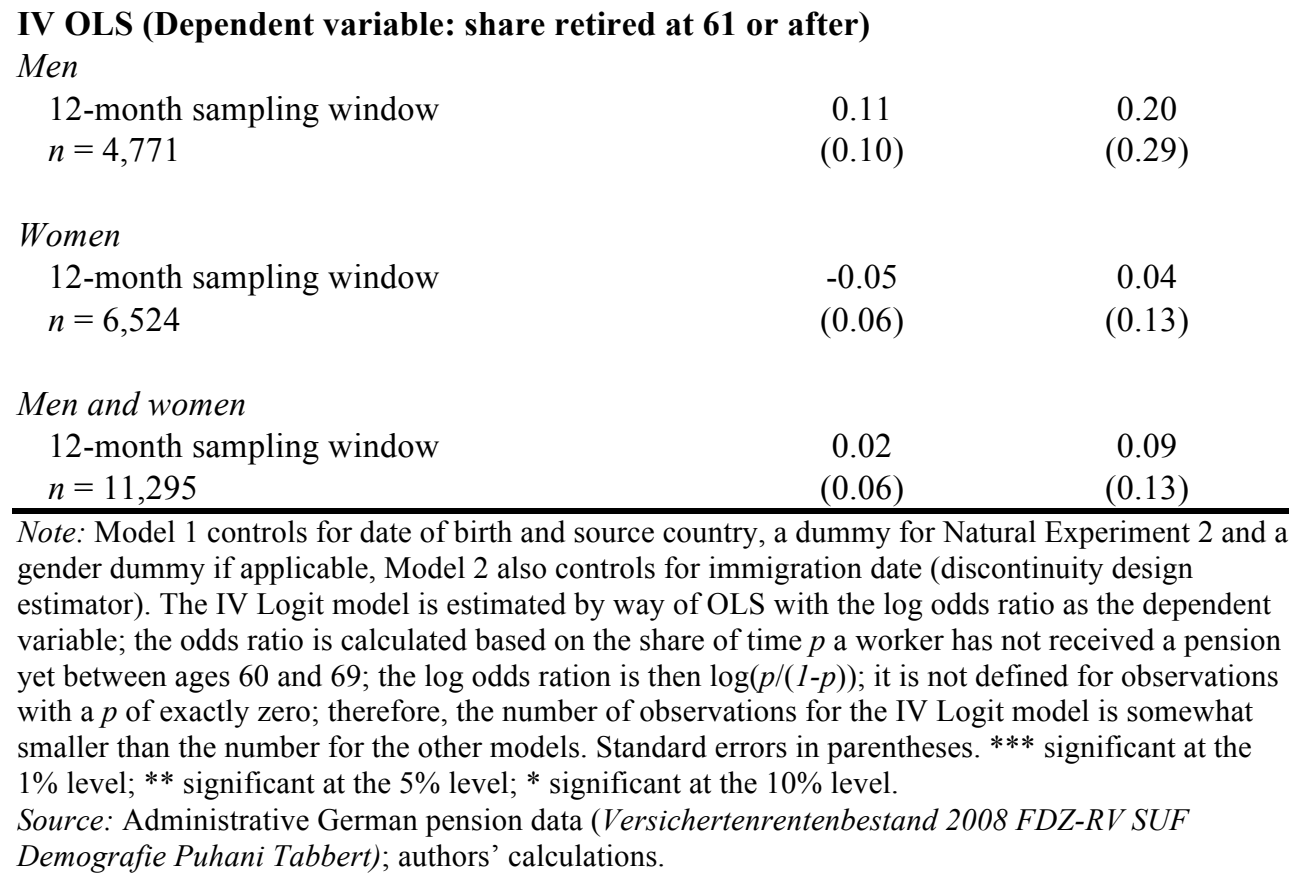


Table 6

Pension receipt and labor force status [in percent]

\begin{tabular}{|c|c|c|c|c|}
\hline & \multirow{2}{*}{$\begin{array}{c}\text { GSOEP } \\
\text { Men }\end{array}$} & \multicolumn{3}{|c|}{ Microcensus } \\
\hline & & Women & Men & Women \\
\hline \multicolumn{5}{|c|}{ Ethnic Germans migrated since 1988} \\
\hline \multicolumn{5}{|c|}{ Without pension receipt } \\
\hline Employed & 51 & 33 & 66 & 52 \\
\hline Unemployment & 10 & 8 & 22 & 12 \\
\hline Not participating & 39 & 59 & 12 & 36 \\
\hline Observations & 72 & 90 & 393 & 434 \\
\hline \multicolumn{5}{|c|}{ With pension receipt } \\
\hline Employed & 0 & 0 & 5 & 12 \\
\hline Unemployment & 1 & 0 & 2 & 1 \\
\hline Not participating & 99 & 100 & 93 & 87 \\
\hline Observations & 74 & 60 & 299 & 407 \\
\hline \multicolumn{5}{|c|}{ Low-skilled Germans } \\
\hline \multicolumn{5}{|c|}{ Without pension receipt } \\
\hline Employed & 60 & 36 & 68 & 39 \\
\hline Unemployment & 4 & 1 & 17 & 6 \\
\hline Not participating & 36 & 63 & 15 & 55 \\
\hline Observations & 636 & 1,208 & 1,637 & 4,314 \\
\hline \multicolumn{5}{|c|}{ With pension receipt } \\
\hline Employed & 5 & 3 & 6 & 9 \\
\hline Unemployment & 0 & 0 & 1 & 1 \\
\hline Not participating & 95 & 97 & 93 & 90 \\
\hline Observations & 314 & 469 & 1,525 & 3,668 \\
\hline
\end{tabular}

Note: All sampled are limited to persons aged 55 to 65 years at the time of observation. Repatriated ethnic Germans have immigrated since 1988 in the smaller sample of the German Socio-Economic Panel and since 1990 in the Microcensus.

Source: German Socio-Economic Panel 1995-1999; German Microcensus 2005; authors' calculations.

Table 7

Occupational distribution [in percent] of workers aged 55-65: repatriated ethnic Germans versus low-skilled and skilled Germans.

\begin{tabular}{lccccccc}
\hline & \multicolumn{3}{c}{ Men } & \multicolumn{4}{c}{ Women } \\
\cline { 2 - 7 } & \multicolumn{3}{c}{ Low- } & \multicolumn{3}{c}{ Low- } \\
& REGs & Sk. & Skilled & REGs & Sk. & Skilled \\
\hline Self-employed w/o employees & 6 & 10 & 10 & 3 & 5 & 7 \\
Self-employed w/ employees & 6 & 6 & 12 & 2 & 2 & 5 \\
Home worker (family business) & 0 & 1 & 1 & 2 & 6 & 4 \\
Civil servant or judge & 4 & 2 & 11 & 1 & 0 & 8 \\
White-collar employee & 29 & 25 & 41 & 42 & 43 & 61 \\
Blue-collar employee & 54 & 56 & 26 & 49 & 44 & 16 \\
\hline Index of dissimilarity to REGs & - & 7 & 28 & - & 6 & 33 \\
\hline
\end{tabular}

Note: $\mathrm{REG}=$ repatriated ethnic Germans immigrated in 1990 or later; low-skilled workers $=$ employed individuals without even apprenticeship education; skilled workers = employed individuals with apprenticeship education or higher.

Source: German Microcensus 2005; authors' calculations. 
Natural Experiment 1: Only Birth Cohorts January 1932 - March 1936 [Age Restriction] and Immigration Cohorts July 1990 - June 1991 [Discontinuity Sample] considered:

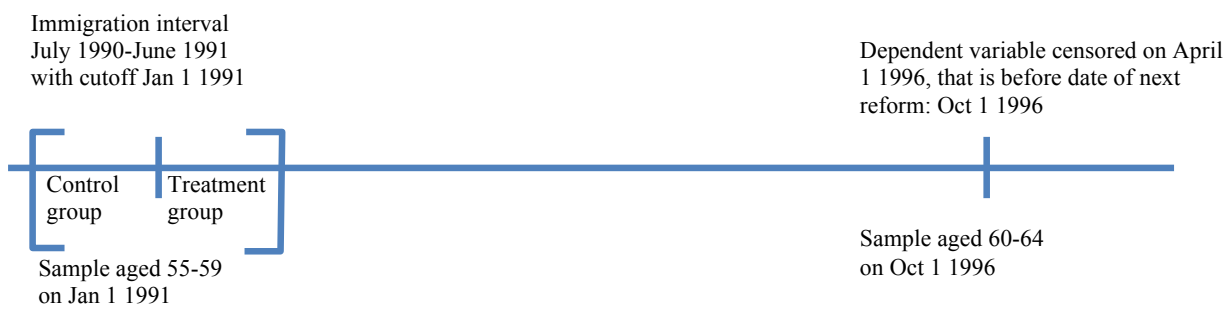

Sample aged 60-64 on Oct 11996

Natural Experiment 2: Only Birth Cohorts January 1937 - December 1941 [Age Restriction] and Immigration Cohorts November 1995 - November 1996 [Discontinuity Sample] considered:

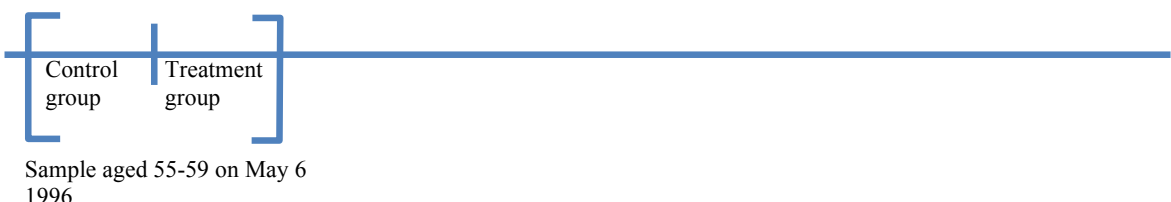

Fig. 1. Timing of pension cuts and sample restrictions for the evaluation of the two natural experiments

Note: The birth cohort restrictions are not illustrated graphically, but mentioned in the headings of the panels and in the text boxes concerning age ranges. The square brackets symbolize start and end dates for date of immigration intervals. For the discontinuity designs, these intervals have a width of at most plus/minus 6 months in relation to the cutoff date, that is 12 months at the maximum. 


\section{A. Natural Experiment 1}

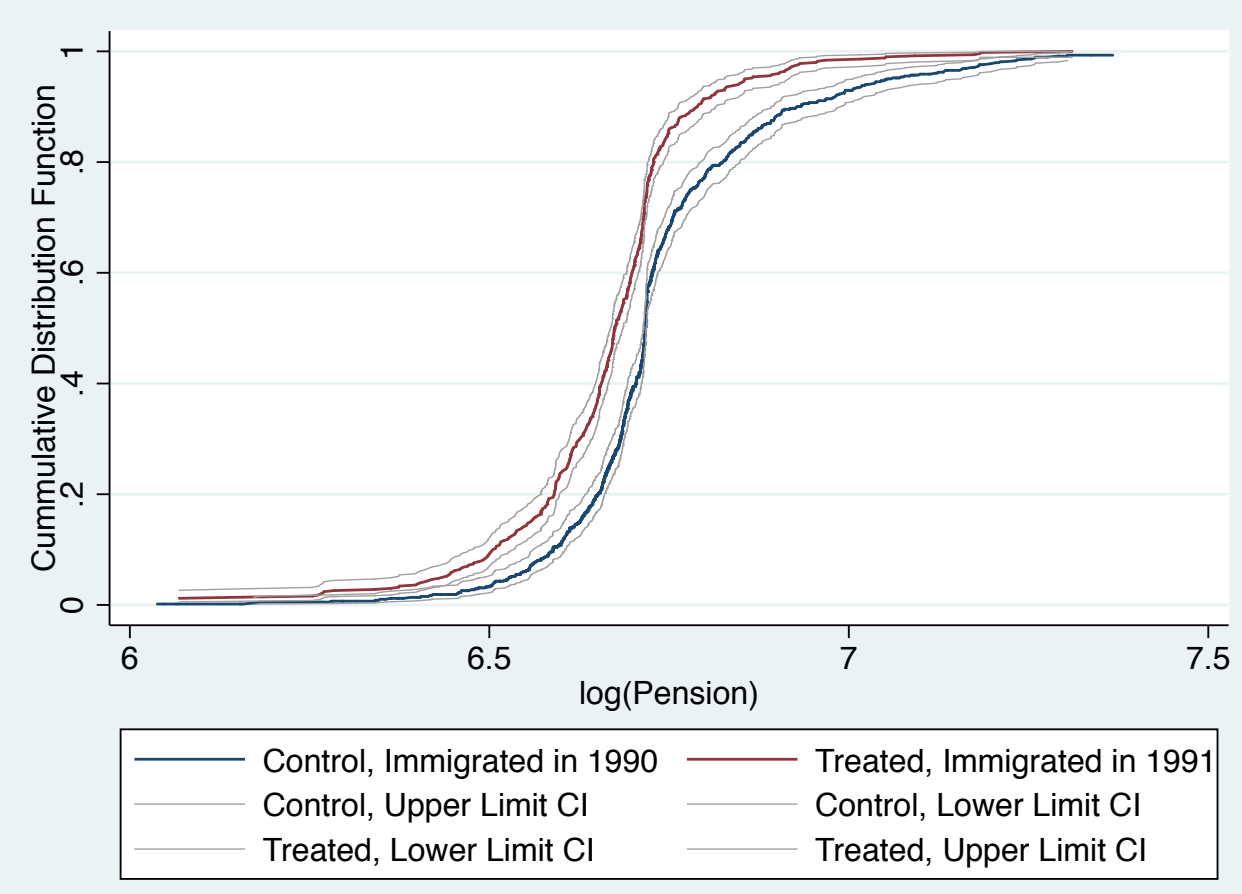

\section{B. Natural Experiment 2}

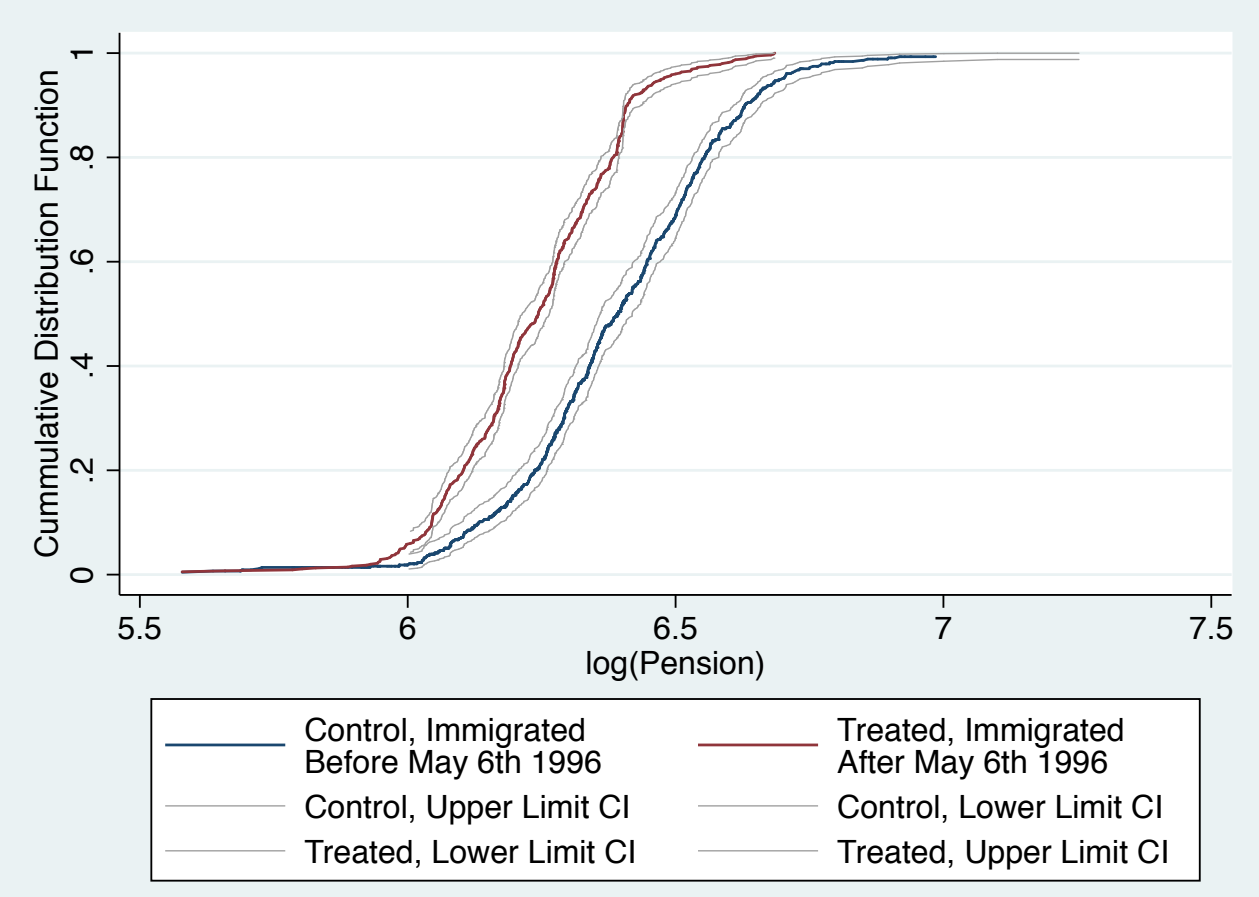

Fig. 2. Cumulative distribution functions of log pension payments for treated and control groups for men. The graphs are based on the data for the 6-month sampling window. The thin grey lines represent $95 \%$ confidence interval (CI) limits.

Source: Administrative German pension data (Versichertenrentenbestand 2008 FDZ-RV SUF Demografie Puhani Tabbert); authors' calculations. 


\section{A. Natural Experiment 1}

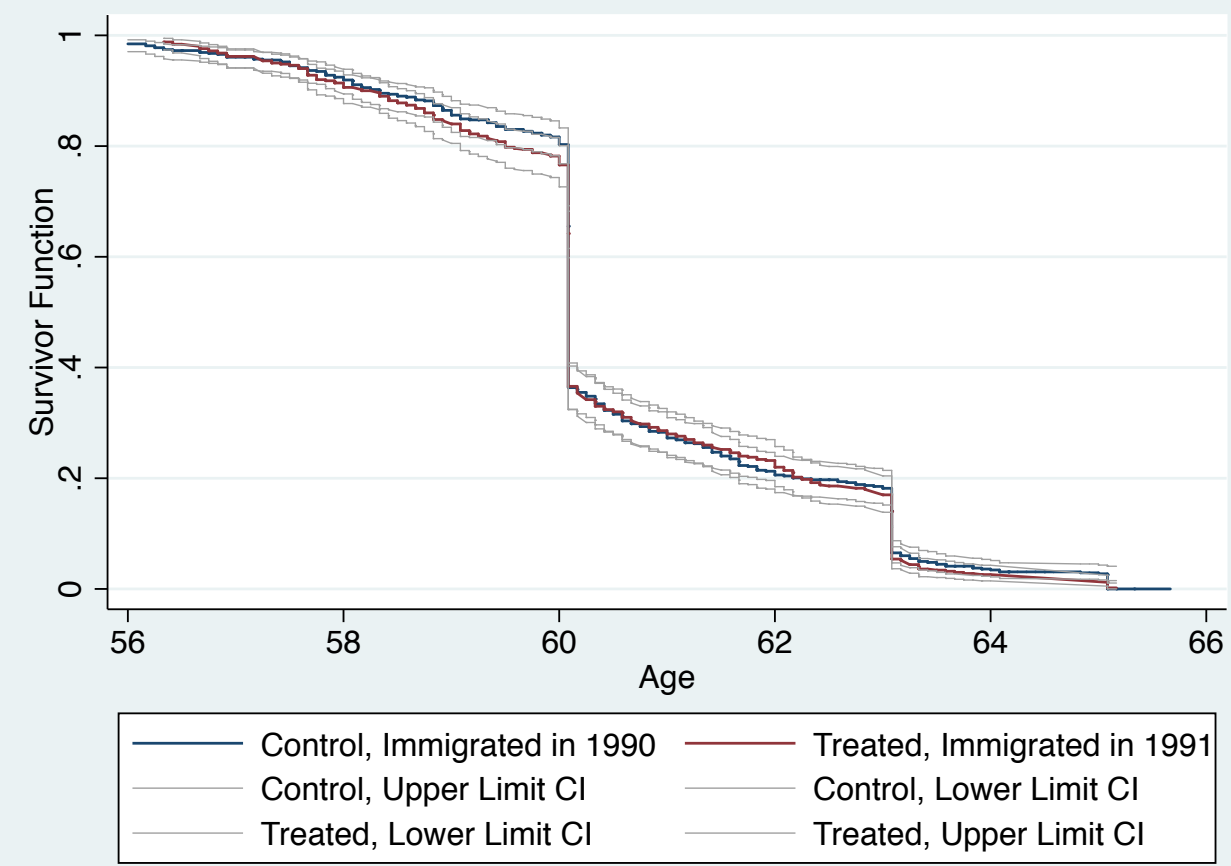

\section{B. Natural Experiment 2}

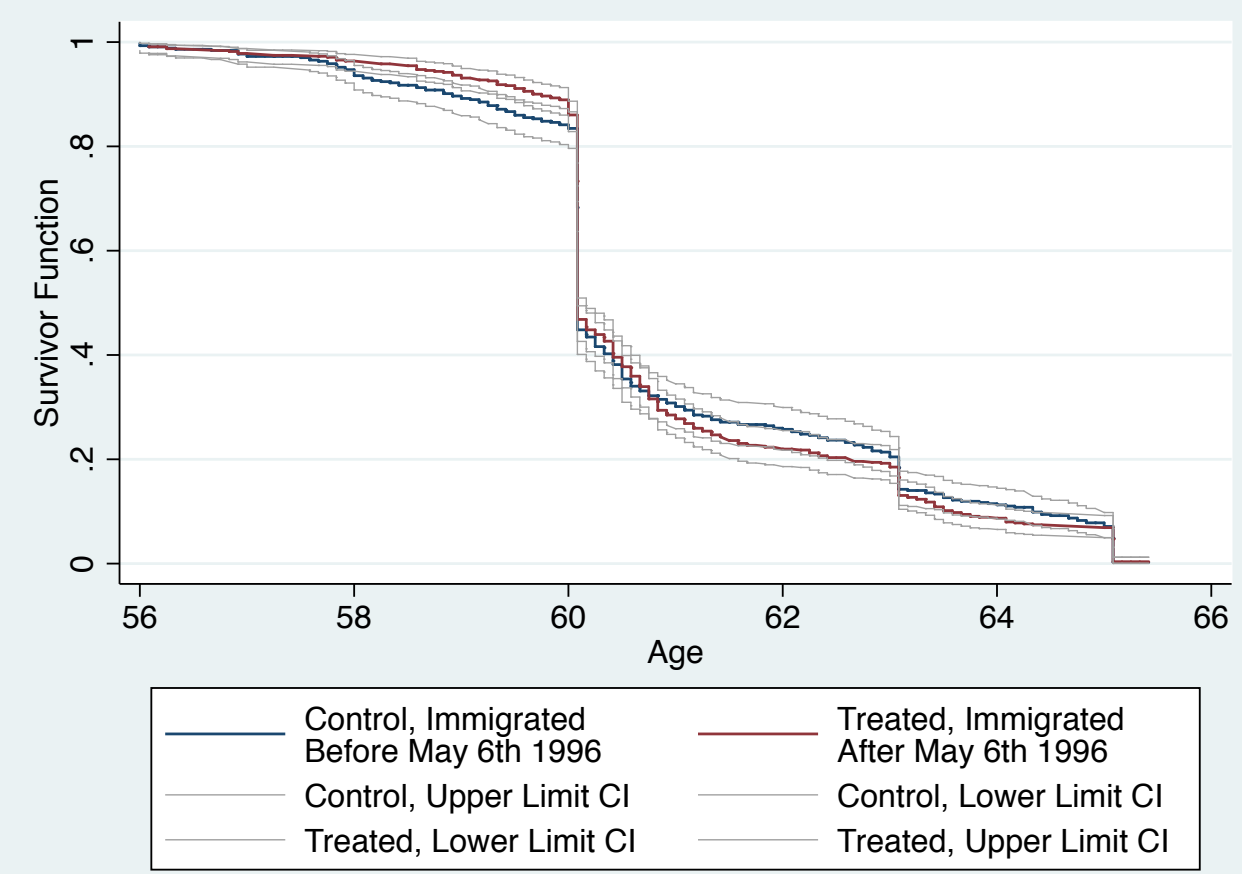

Fig. 3. Survival estimates for age of first pension receipt for treated and control groups for men. The graphs are based on the data for the 6-month sampling window. The thin grey lines represent $95 \%$ confidence interval (CI) limits.

Source: Administrative German pension data (Versichertenrentenbestand 2008 FDZ-RV SUF Demografie Puhani Tabbert); authors' calculations. 


\section{A. Natural Experiment 1}

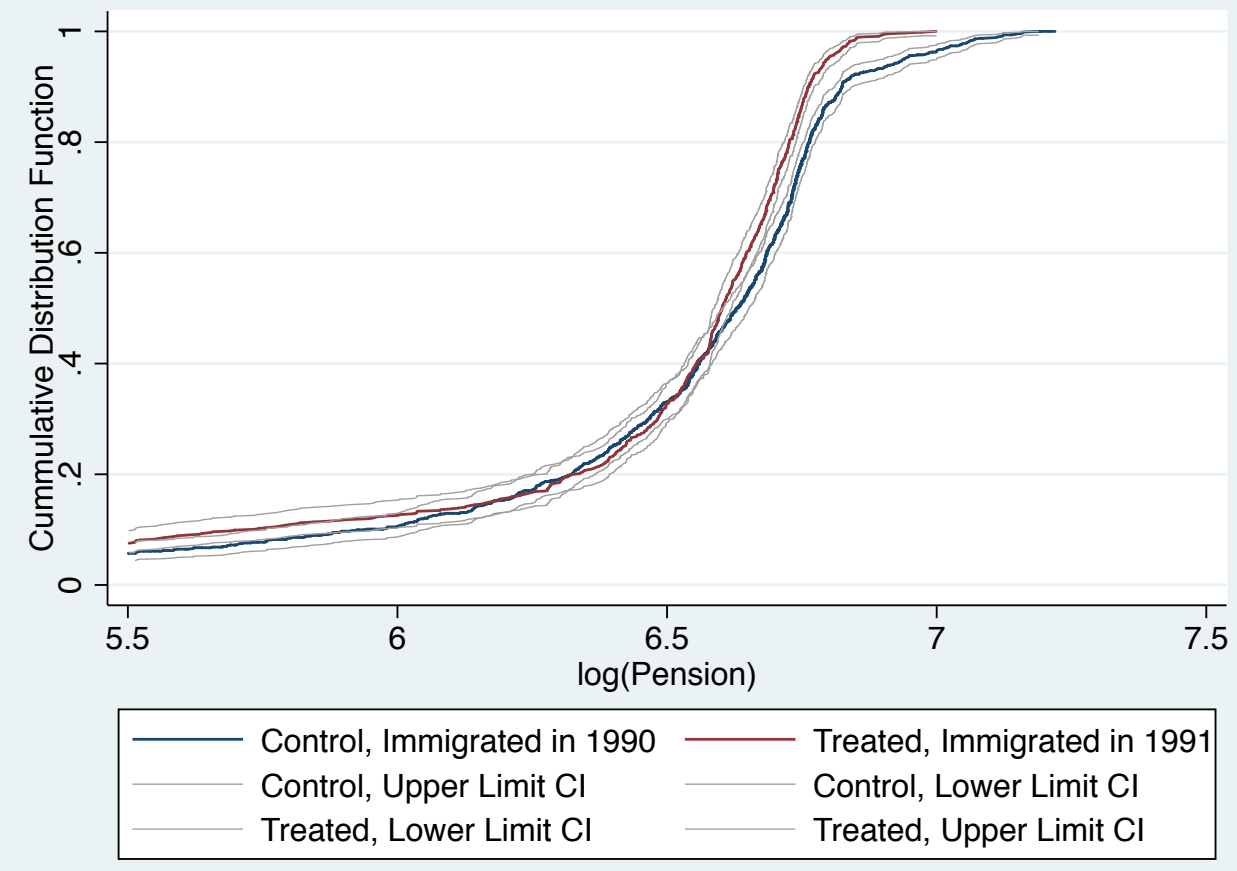

\section{B. Natural Experiment 2}

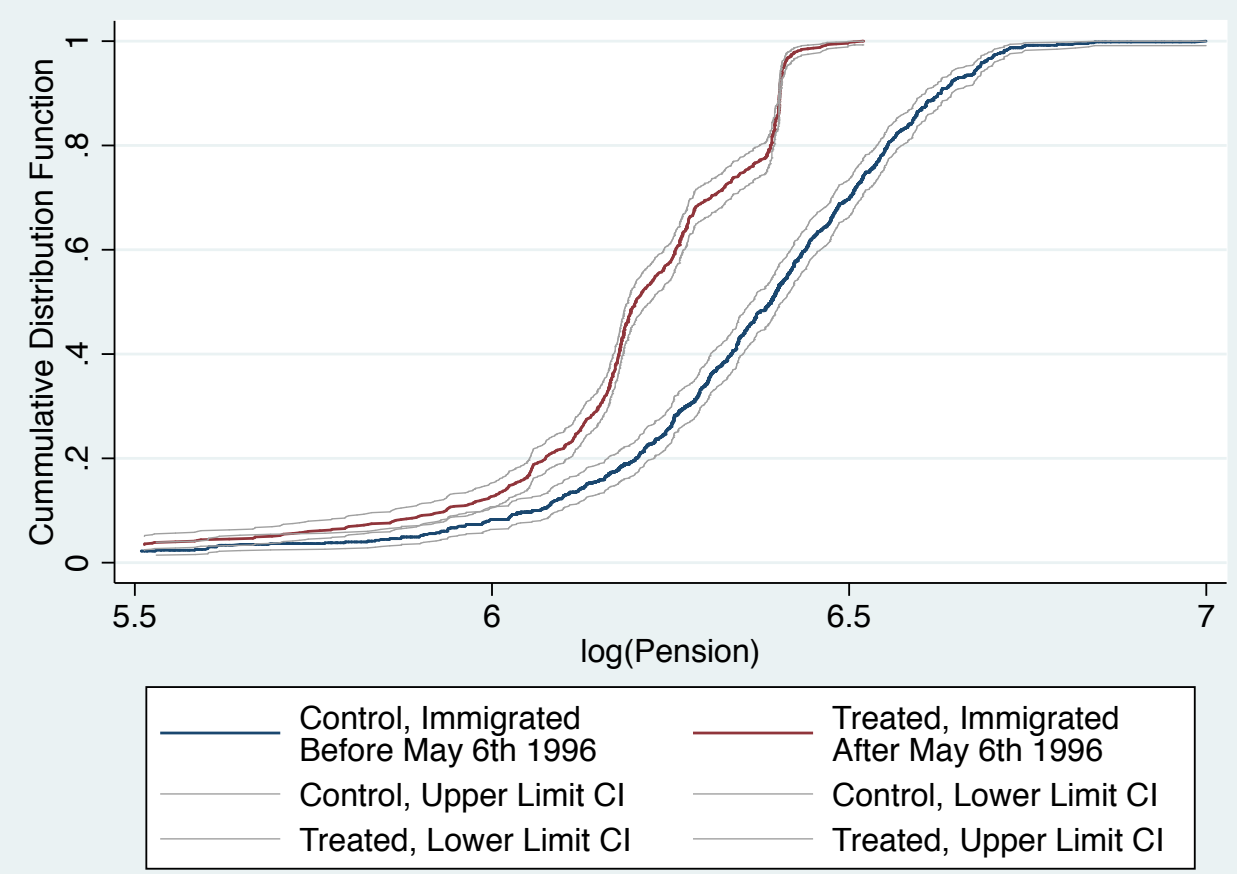

Fig. 4. Cumulative distribution functions of $\log$ pension payments for treated and control groups for women. The graphs are based on the data for the 6-month sampling window. The thin grey lines represent $95 \%$ confidence interval (CI) limits.

Source: Administrative German pension data (Versichertenrentenbestand 2008 FDZ-RV SUF Demografie Puhani Tabbert); authors' calculations. 


\section{A. Natural Experiment 1}

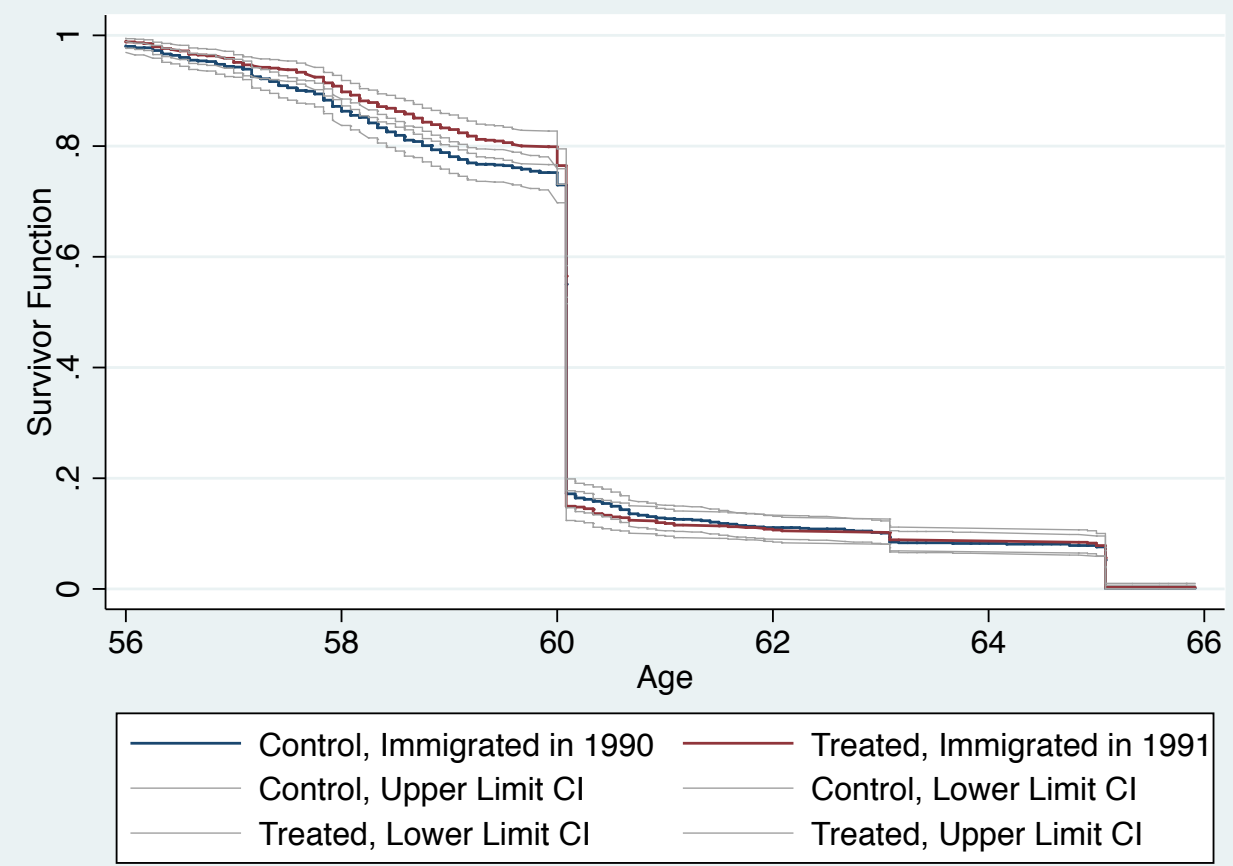

\section{B. Natural Experiment 2}

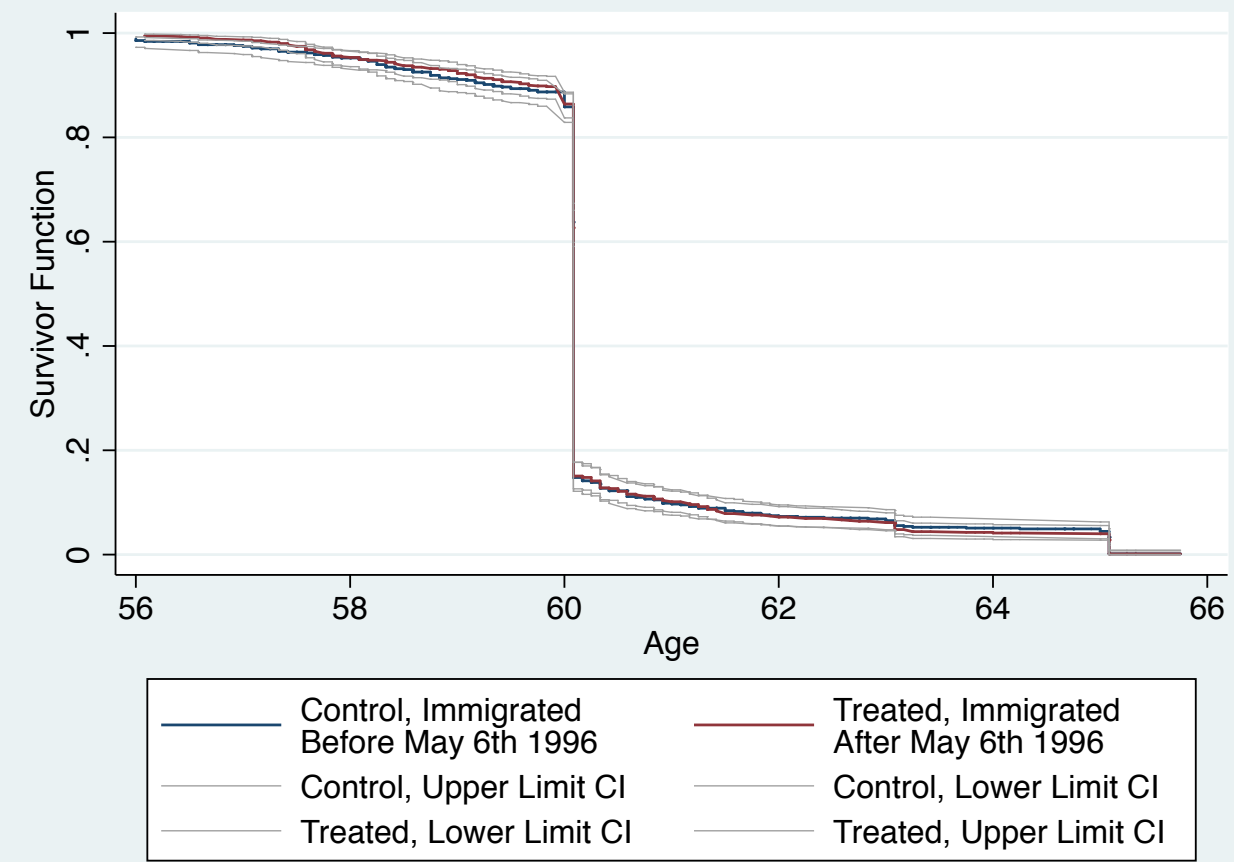

Fig. 5. Survival estimates for age of first pension receipt for treated and control groups for women. The graphs are based on the data for the 6-month sampling window. The thin grey lines represent $95 \%$ confidence interval (CI) limits.

Source: Administrative German pension data (Versichertenrentenbestand 2008 FDZ-RV SUF Demografie Puhani Tabbert); authors' calculations. 
A. Men

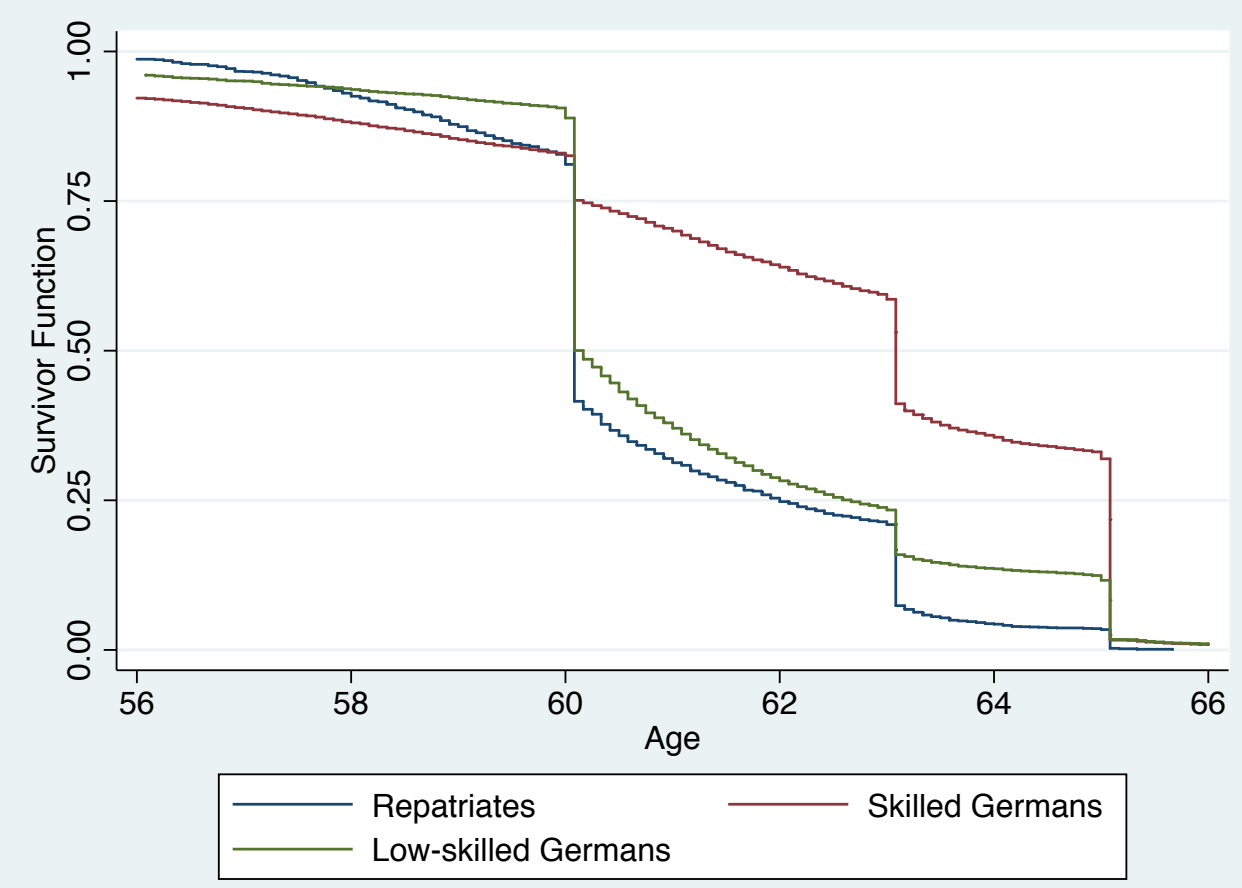

B. Women

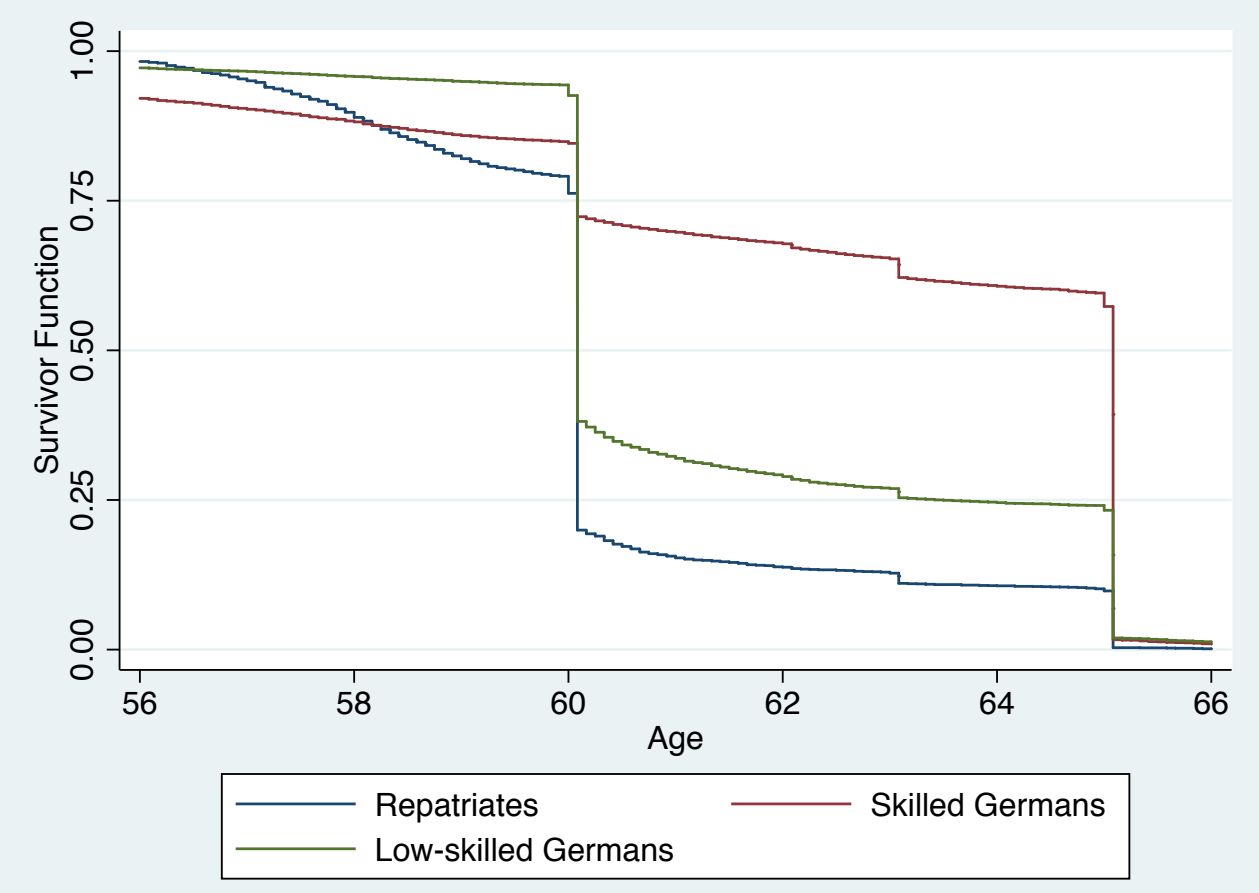

Fig. 6. Survival estimates for age of first pension receipt: birth cohorts January 1932 to March 1936, for repatriated ethnic Germans additional restriction: immigration between June 1990 and June 1991.

Source: Administrative German pension data (Versichertenrentenbestand 2008 FDZ-RV SUF Demografie Puhani Tabbert); authors' calculations. 
Online Appendix. - Additional Tables and Figures

Table A1

Estimation results for Natural Experiment 1.

\begin{tabular}{|c|c|c|c|}
\hline & Model 1 & Model 2 & Model 3 \\
\hline \multicolumn{4}{|c|}{ Estimated change in log pension wealth } \\
\hline \multicolumn{4}{|c|}{$M e n-O L S$} \\
\hline $\begin{array}{l}\text { 12-month sampling window } \\
n=2,554\end{array}$ & $\begin{array}{c}-0.07 * * * \\
(0.01)\end{array}$ & $\begin{array}{c}-0.07 * * * \\
(0.01)\end{array}$ & $\begin{array}{c}-0.09 * * * \\
(0.02)\end{array}$ \\
\hline $\begin{array}{l}\text { 6-month sampling window } \\
n=1,088\end{array}$ & $\begin{array}{c}-0.08 * * * \\
(0.01)\end{array}$ & $\begin{array}{c}-0.07 * * * \\
(0.02)\end{array}$ & $\begin{array}{c}-0.07 * * \\
(0.03)\end{array}$ \\
\hline \multicolumn{4}{|l|}{ Women - OLS } \\
\hline $\begin{array}{l}\text { 12-month sampling window } \\
n=3,405\end{array}$ & $\begin{array}{c}-0.07 * * * \\
(0.02)\end{array}$ & $\begin{array}{c}-0.06 * * \\
(0.03)\end{array}$ & $\begin{array}{l}-0.06 \\
(0.05)\end{array}$ \\
\hline $\begin{array}{l}\text { 6-month sampling window } \\
n=1,486\end{array}$ & $\begin{array}{c}-0.07 * * * \\
(0.02)\end{array}$ & $\begin{array}{l}-0.04 \\
(0.04)\end{array}$ & $\begin{array}{l}-0.05 \\
(0.07)\end{array}$ \\
\hline \multicolumn{4}{|l|}{ Men and women - OLS } \\
\hline $\begin{array}{l}\text { 12-month sampling window } \\
n=5,959\end{array}$ & $\begin{array}{c}-0.07 * * * \\
(0.01)\end{array}$ & $\begin{array}{c}-0.06 * * * \\
(0.02)\end{array}$ & $\begin{array}{c}-0.08 * * * \\
(0.03)\end{array}$ \\
\hline $\begin{array}{l}\text { 6-month sampling window } \\
n=2,574\end{array}$ & $\begin{array}{c}-0.07 * * * \\
(0.01)\end{array}$ & $\begin{array}{c}-0.06^{* *} \\
(0.03)\end{array}$ & $\begin{array}{l}-0.08^{*} \\
(0.05)\end{array}$ \\
\hline
\end{tabular}

Estimated effect [in years] of pension cuts on age of first pension receipt Men - Tobit

12-month sampling window

$-0.12$

$-0.04$

$-0.26$

$n=2,554$

(0.07)

$(0.15)$

$(0.24)$

6-month sampling window

$-0.03$

$-0.29$

$n=1,088$

(0.10)

$(0.22)$

$-0.14$

(0.35)

Women - Tobit

12-month sampling window

$0.15 * * *$

0.12

0.14

$n=3,405$

$(0.06)$

$(0.12)$

(0.19)

6-month sampling window

0.15 *

0.13

$-0.16$

$n=1,486$

(0.08)

(0.17)

$(0.27)$

Men and women - Tobit

12-month sampling window

$n=5,959$

$\begin{array}{ccc}0.04 & 0.05 & -0.04 \\ (0.05) & (0.09) & (0.15) \\ 0.07 & -0.04 & -0.15 \\ (0.06) & (0.13) & (0.21)\end{array}$

6-month sampling window

$n=2,574$

(0.06)

$(0.13)$

(0.21)

Note: Model 1 controls for date of birth and source country, and a gender dummy if applicable, Model 2 also controls for immigration date (discontinuity design estimator), and Model 3 additionally controls for the square of the immigration date (discontinuity design estimator). Standard errors in parentheses. ${ }^{* * *}$ significant at the $1 \%$ level; ** significant at the $5 \%$ level; * significant at the $10 \%$ level.

Source: Administrative German pension data (Versichertenrentenbestand 2008 FDZ-RV SUF Demografie Puhani Tabbert); authors' calculations. 
Table A2

Estimation Results for Natural Experiment 2.

\begin{tabular}{|c|c|c|c|}
\hline & Model 1 & Model 2 & Model 3 \\
\hline \multicolumn{4}{|c|}{ Estimated change in log pension wealth } \\
\hline \multicolumn{4}{|c|}{$M e n-O L S$} \\
\hline 12-month sampling window & $-0.21 * * *$ & $-0.11 * * *$ & $-0.10 * *$ \\
\hline$n=2,217$ & $(0.01)$ & $(0.03)$ & $(0.04)$ \\
\hline 6-month sampling window & $-0.14 * * *$ & $-0.13 * * *$ & $-0.16 * * *$ \\
\hline$n=989$ & $(0.02)$ & $(0.04)$ & $(0.04)$ \\
\hline \multicolumn{4}{|l|}{ Women - OLS } \\
\hline 12-month sampling window & $-0.19 * * *$ & $-0.18 * * *$ & $-0.18 * * *$ \\
\hline$n=3,119$ & $(0.01)$ & $(0.02)$ & $(0.03)$ \\
\hline 6-month sampling window & $-0.18 * * *$ & $-0.19 * * *$ & $-0.17 * * *$ \\
\hline$n=1,387$ & $(0.01)$ & $(0.03)$ & $(0.04)$ \\
\hline \multicolumn{4}{|l|}{ Men and women - OLS } \\
\hline 12-month sampling window & $-0.20 * * *$ & $-0.15 * * *$ & $-0.15 * * *$ \\
\hline$n=5,336$ & $(0.01)$ & $(0.02)$ & $(0.02)$ \\
\hline 6-month sampling window & $-0.16 * * *$ & $-0.16^{* * *}$ & $-0.16 * * *$ \\
\hline$n=2,376$ & $(0.01)$ & $(0.02)$ & $(0.03)$ \\
\hline
\end{tabular}

Estimated effect [in years] of pension cuts on age of first pension receipt Men - OLS

$\begin{array}{lccc}\text { 12-month sampling window } & 0.09 & -0.08 & 0.08 \\ n=2,217 & (0.08) & (0.16) & (0.24) \\ \text { 6-month sampling window } & 0.00 & 0.05 & 0.41 \\ n=989 & (0.12) & (0.22) & (0.33)\end{array}$

Women - OLS

12-month sampling window

$\begin{array}{lll}0.09 * & 0.00 & -0.04\end{array}$

$n=3,119$

$(0.05)$

$(0.10)$

$(0.16)$

6-month sampling window

0.04

$-0.08$

0.04

$n=1,387$

$(0.08)$

$(0.15)$

$(0.23)$

Men and women - OLS

12-month sampling window

$\begin{array}{ccc}0.09^{*} & -0.03 & -0.01 \\ (0.05) & (0.09) & (0.14) \\ 0.03 & -0.05 & 0.13 \\ (0.07) & (0.13) & (0.20)\end{array}$

Note: Model 1 controls for date of birth and source country, and a gender dummy if applicable, Model 2 also controls for immigration date (discontinuity design estimator), and Model 3 additionally controls for the square of the immigration date (discontinuity design estimator). Standard errors in parentheses. ${ }^{* * *}$ significant at the $1 \%$ level; ** significant at the $5 \%$ level; * significant at the $10 \%$ level.

Source: Administrative German pension data (Versichertenrentenbestand 2008 FDZ-RV SUF Demografie Puhani Tabbert); authors' calculations. 
A

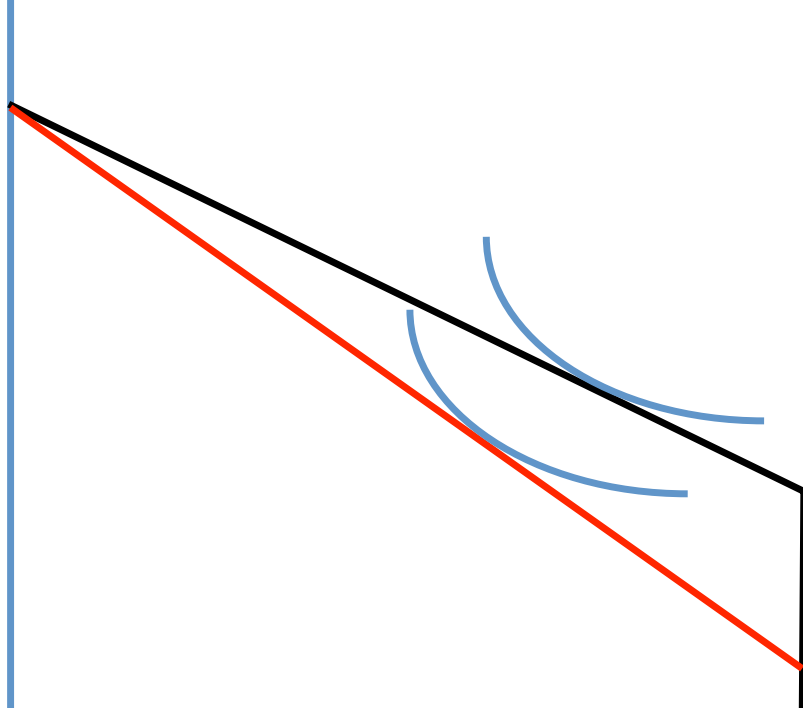

The point at the kink of the budget constraint

indeates the maximum consumption level at the earliest point of retirement; for the cohorts of repatriated ethnic

Germans investigated here, this is mostly determined by earnings points acquired abroad; Natural Experiments 1 and 2 decreased these earnings points and hence shifted the kink to a lower consumption level.

No retirement-

here the cut in earnings points due to the reform

has no effect on

consumption

\section{Maximum years Leisure of retiremer \\ corresponds to earlies possible retirement; here the cut in earnings points due to the reform has the largest effect on consumption}

Fig. A1. Illustration why Natural Experiments 1 and 2 theoretically lead to later retirement (less leisure) if workers are initially at an interior solution (note that both substitution and income effects work in the same direction in this case); here we assume that pension receipt concurs with retirement

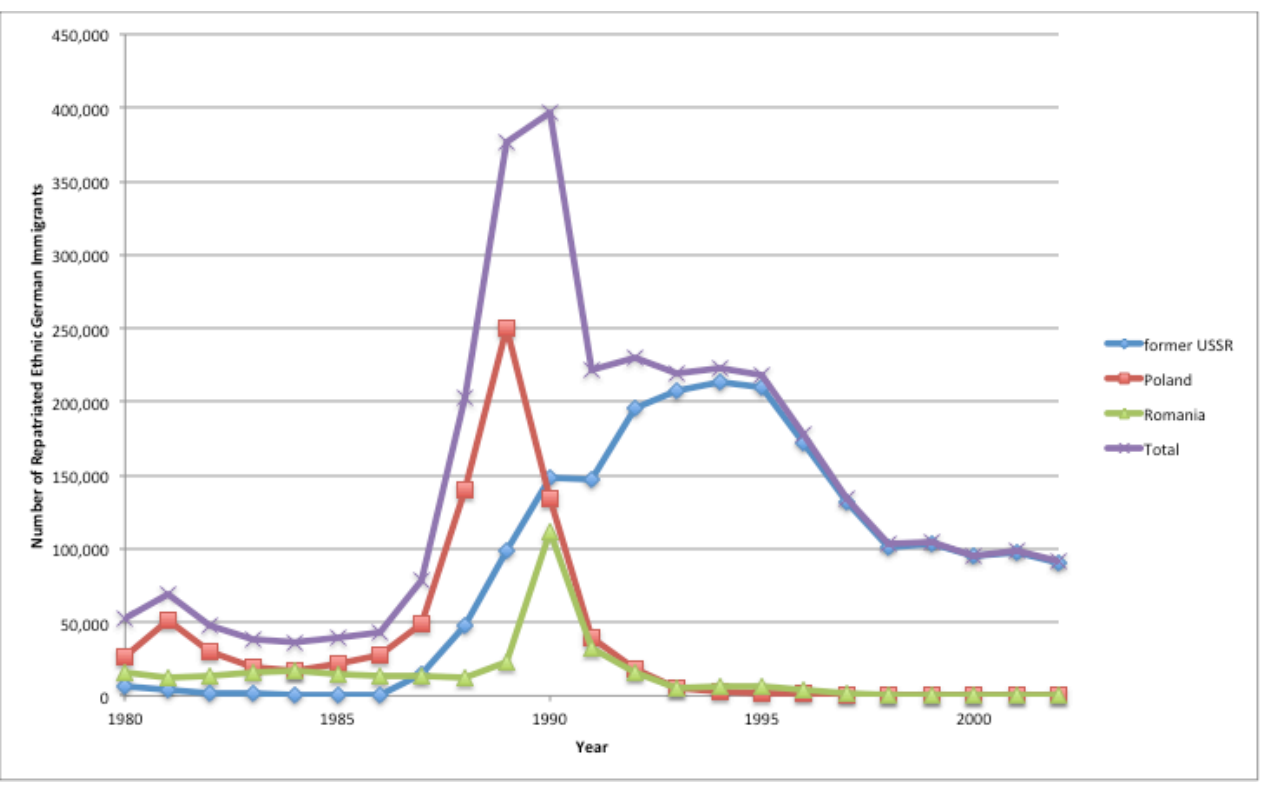

Fig. A2. Number of Repatriated Ethnic German Immigrants by Year and Source Country Source: German Federal Ministry of the Interior. 


\section{A. Natural Experiment 1}

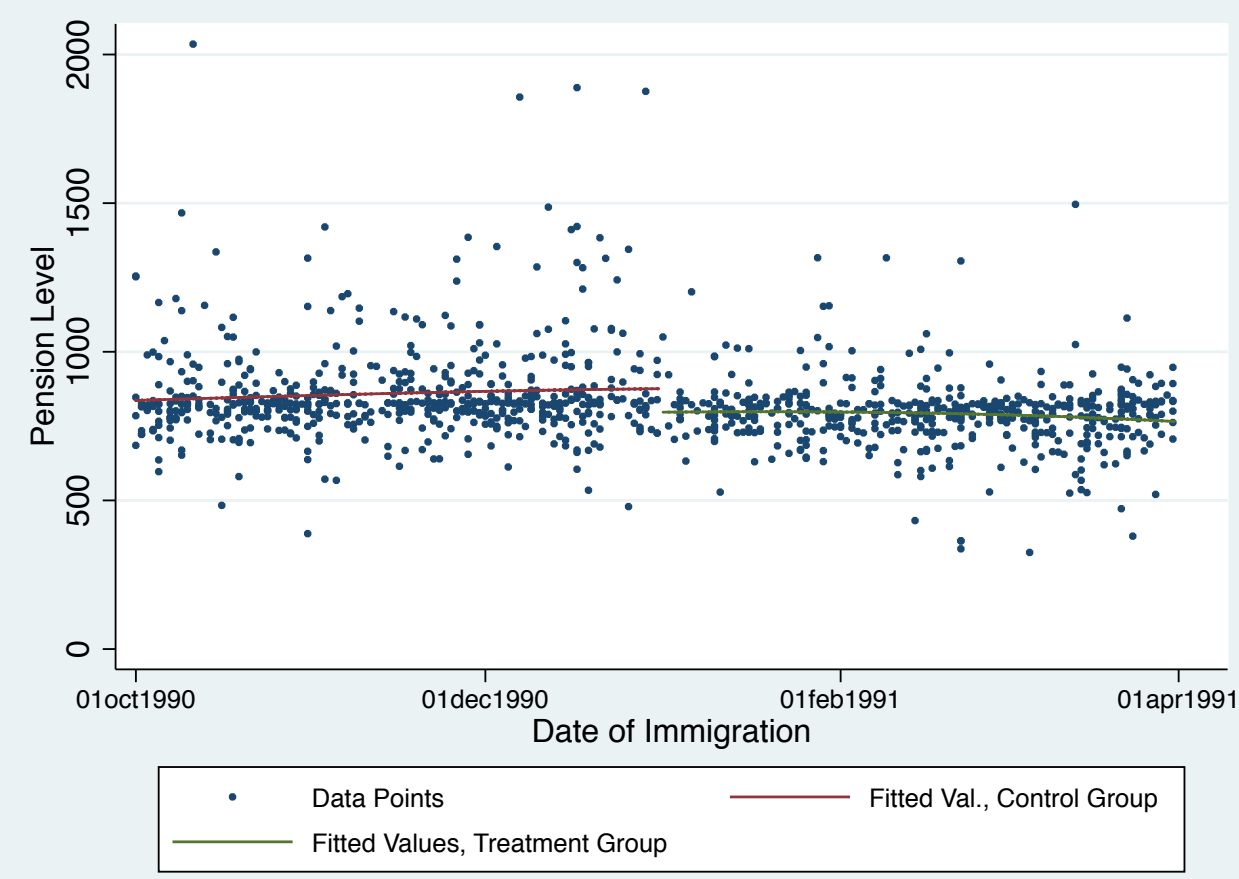

\section{B. Natural Experiment 2}

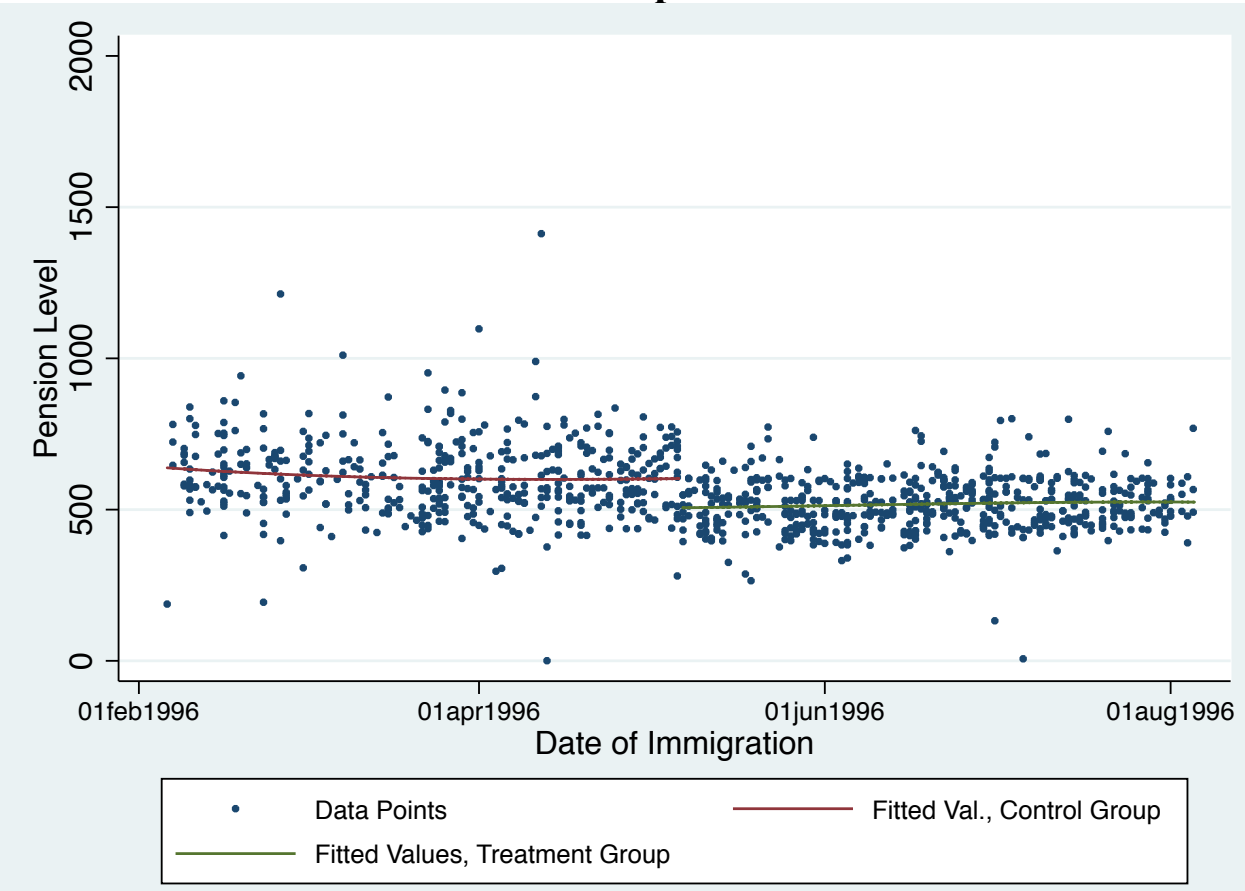

Fig. A3. Pension payments and date of immigration: men. The graphs are based on the data for the 6-month sampling window. Fitted values are based on a third-order polynomial.

Source: Administrative German pension data (Versichertenrentenbestand 2008 FDZ-RV SUF Demografie Puhani Tabbert); authors' calculations. 


\section{A. Natural Experiment 1}

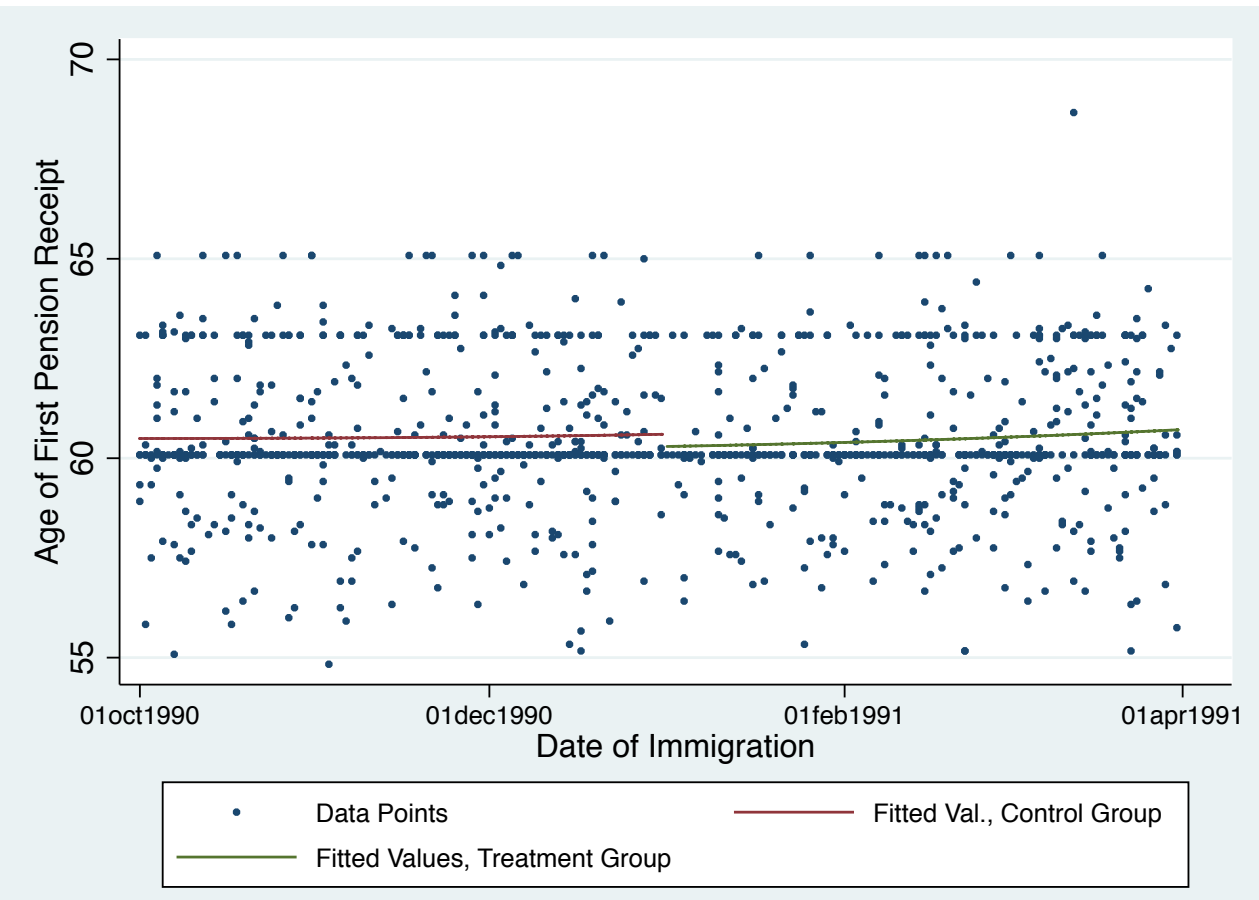

B. Natural Experiment 2

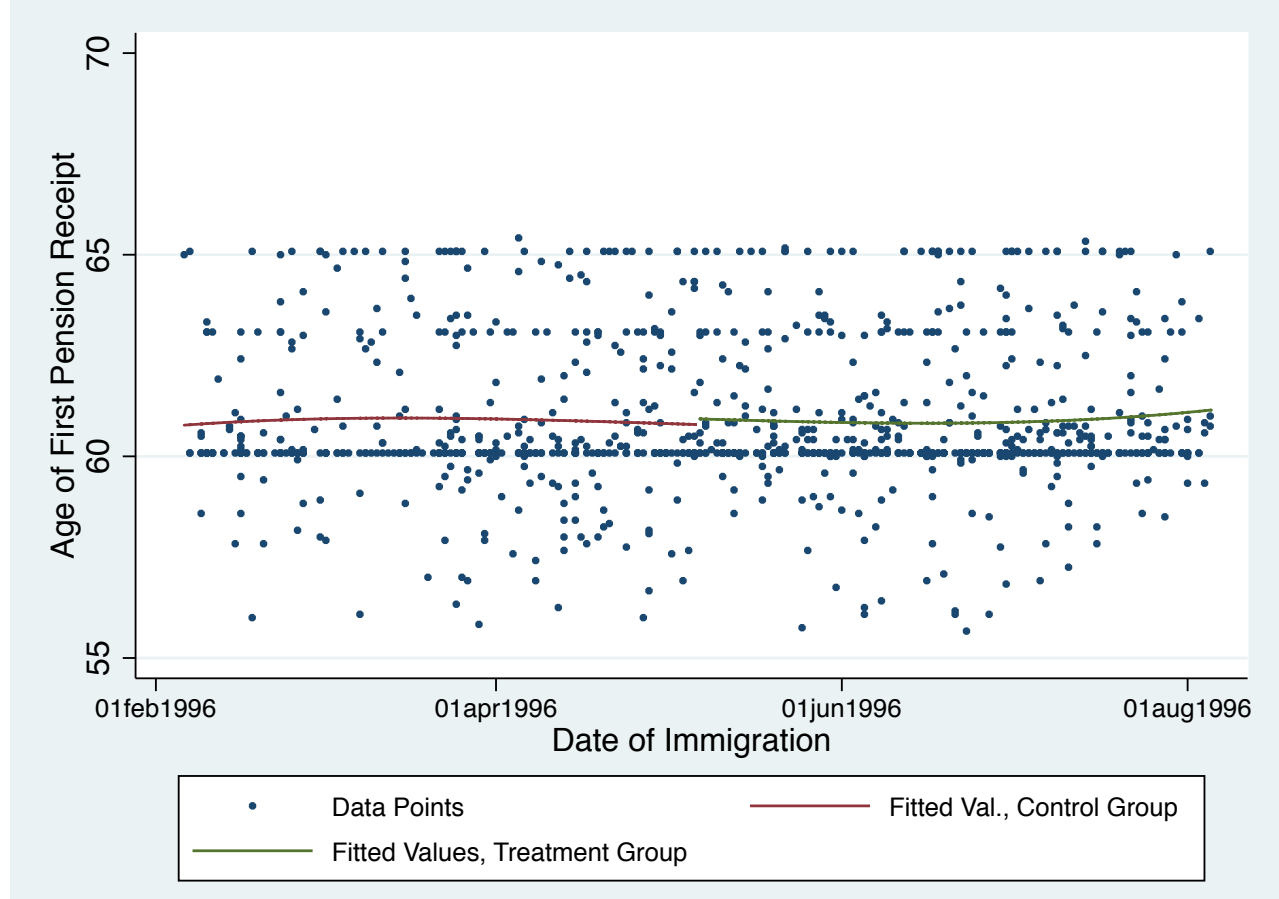

Fig. A4. Age of first pension receipt and date of immigration: men. The graphs are based on the data for the 6-month sampling window. Fitted values are based on a third-order polynomial.

Source: Administrative German pension data (Versichertenrentenbestand 2008 FDZ-RV SUF Demografie Puhani Tabbert); authors' calculations. 


\section{A. Natural Experiment 1}

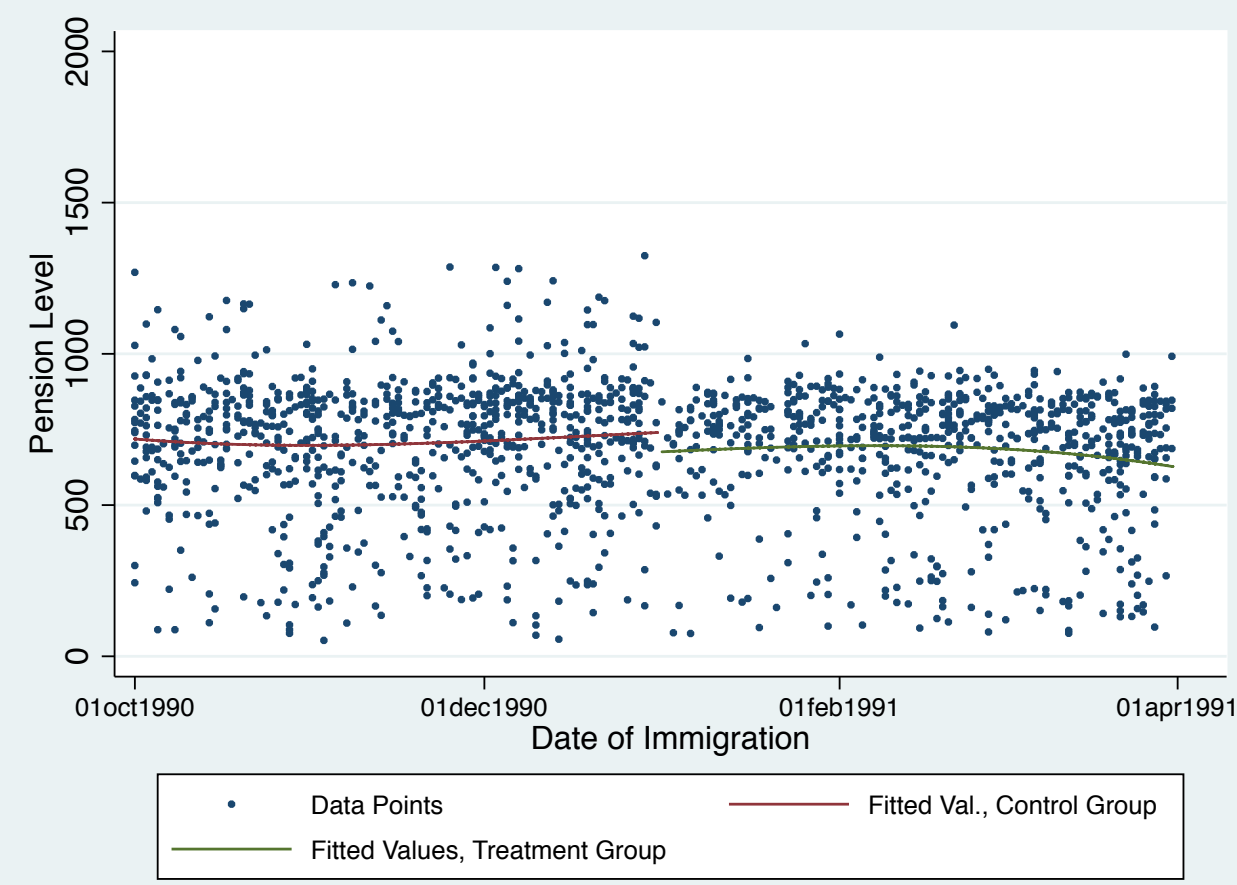

B. Natural Experiment 2

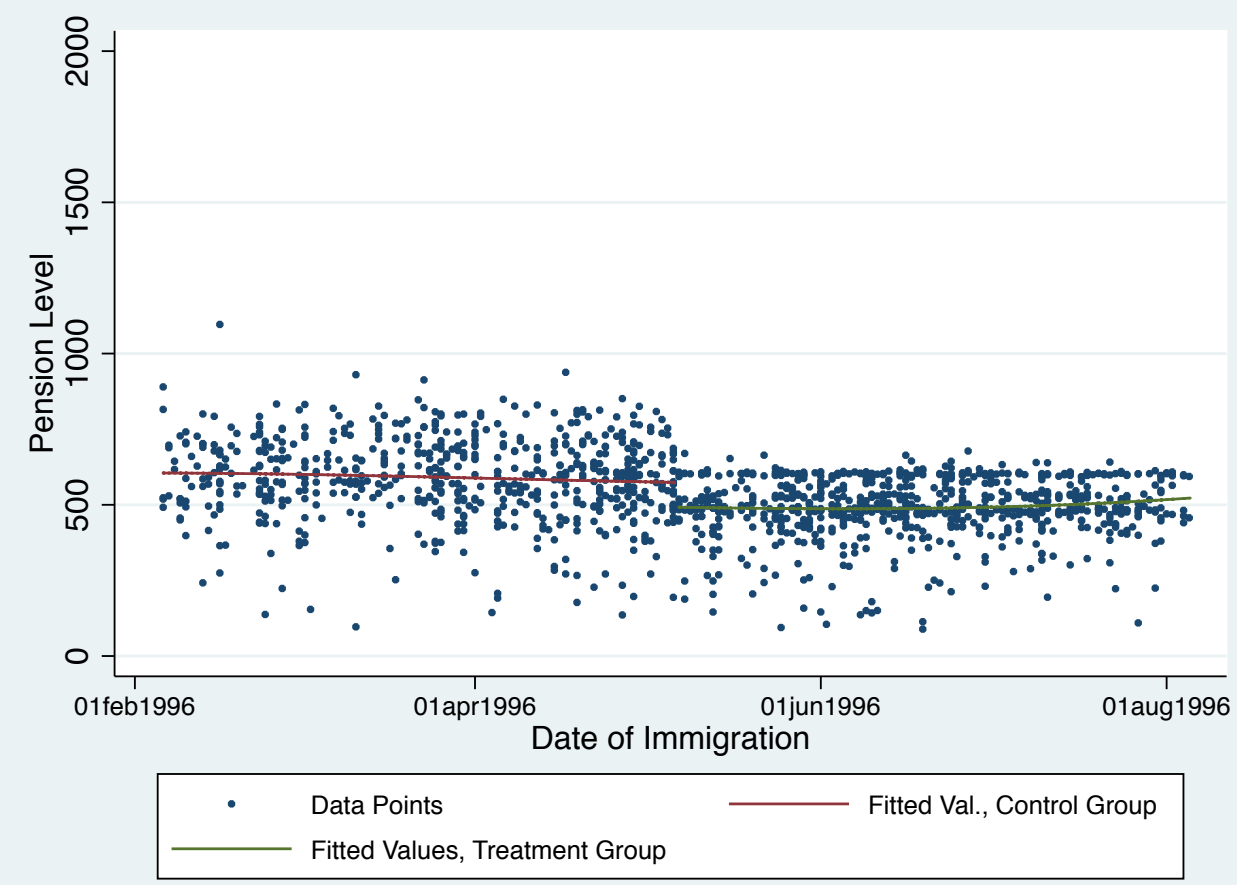

Fig. A5. Pension payments and date of immigration: women. The graphs are based on the data for the 6-month sampling window. Fitted values are based on a third-order polynomial.

Source: Administrative German pension data (Versichertenrentenbestand 2008 FDZ-RV SUF Demografie Puhani Tabbert); authors' calculations. 
A. Natural Experiment 1

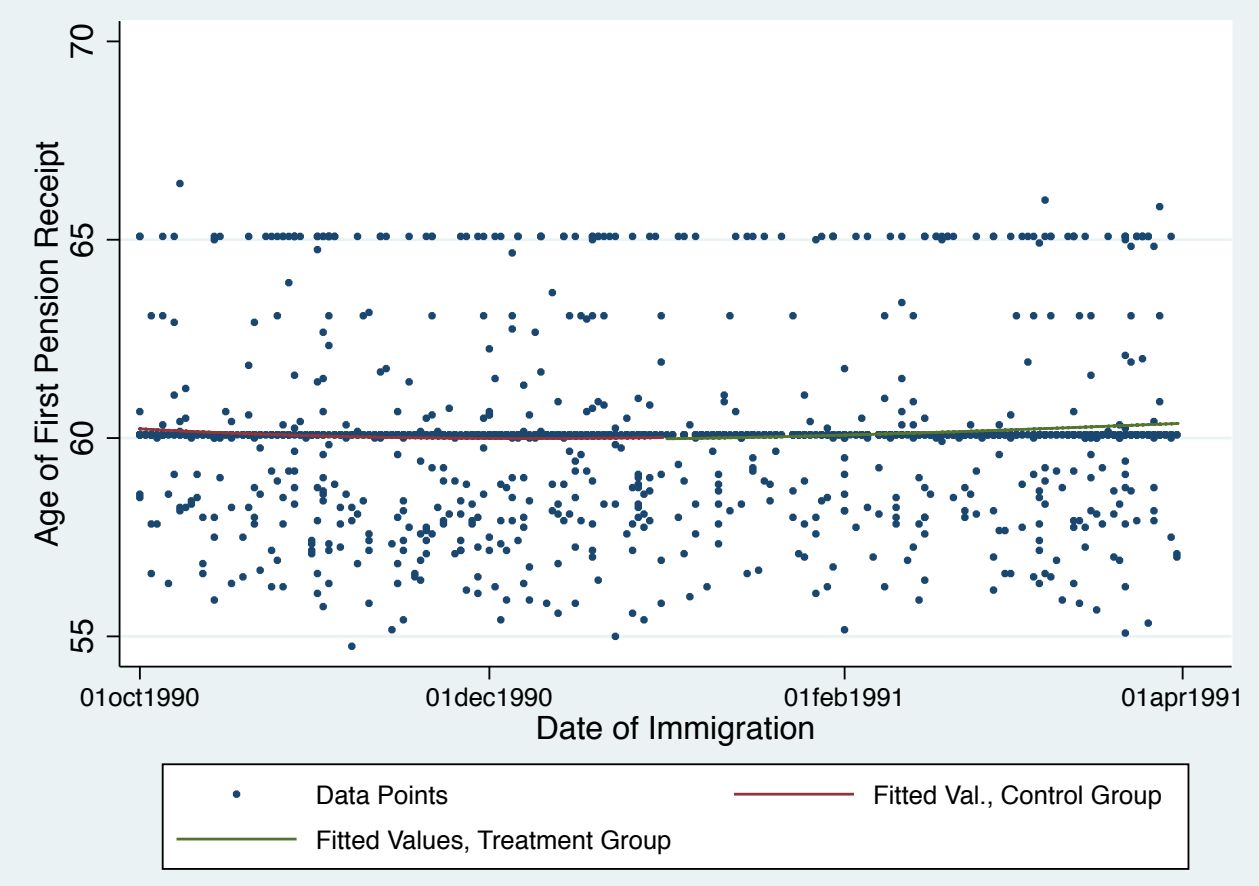

B. Natural Experiment 2

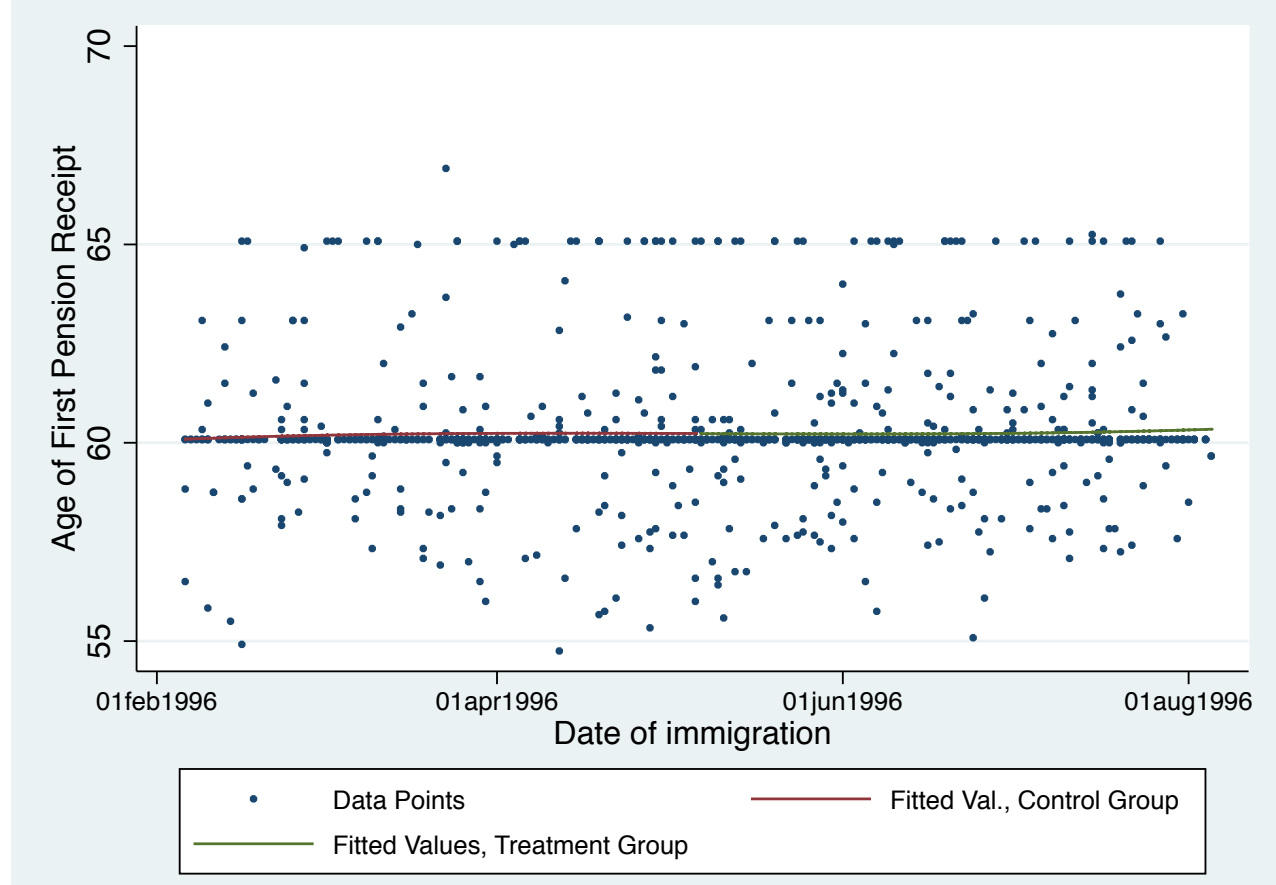

Fig. A6. Age of first pension receipt and date of immigration: women. The graphs are based on the data for the 6-month sampling window. Fitted values are based on a thirdorder polynomial.

Source: Administrative German pension data (Versichertenrentenbestand 2008 FDZ-RV SUF Demografie Puhani Tabbert); authors' calculations. 